\title{
Morphological transition triggered by mannose conjugation to a cyclic hexapeptide
}

\author{
Apurba K. Barman, ${ }^{a}$ Nidhi Gour, ${ }^{a, c}$ and Sandeep Verma ${ }^{* a, b}$ \\ ${ }^{a}$ Department of Chemistry, Indian Institute of Technology Kanpur, Kanpur-298 916 UP, India \\ ${ }^{b}$ DST Unit of Excellence in Soft Nanofabrication, Indian Institute of Technology Kanpur \\ ${ }^{c}$ Current address: Department of Inorganic and Analytical Chemistry, University of Geneva - \\ Sciences II; 30, quai Ernest-Ansermet, CH-1211 Geneva 4, Switzerland \\ E-mail: sverma@iitk.ac.in
}

Dedicated to Prof. Richard R Schmidt on the occasion of his 78th anniversary

\begin{abstract}
The present manuscript describes a facile synthesis and the self-assembling behavior of a cyclic hexapeptide functionalized with mannose residues. Cyclic hexapeptides synthesized through cyclodimerization of tripeptides was conjugated to carbohydrate using click reaction. When selfassembling property of this novel conjugate was studied it afforded spherical morphology which was drastically different from self-assembled nanotubes formed by pristine cyclic peptide. Thus, functionalization of mannose to cyclic hexapeptide triggers morphological transition from tubular to spherical structure, opening new avenue for controlled manipulation and modification of peptide based self-assembled structures.
\end{abstract}

Keywords: Cyclic peptide, cyclodimerization, click reaction, mannose, self-assembly

\section{Introduction}

Cyclic peptides found in variety of bioactive metabolites have been selected as lead compounds for development of various drugs. ${ }^{1,2}$ They are superior to their linear counterparts for applications in vivo as they are more permeable and more resistant to degradation by both exoand endoproteases due to absence of $\mathrm{C}$ - and $\mathrm{N}$-termini. ${ }^{3}$ Due to conformational rigidity in cyclic peptides various functional groups could be spatially arranged in a predetermined manner and this also makes them useful candidate for studying protein folding. ${ }^{4}$

Apart from direct utility as drugs or bioactive agents, self-assembly of cyclic peptides into various structures, notably nanotubes, have gained attention in recent past due to their applicability in various fields. Pioneering work by Ghadiri et al which showed that cyclic 
peptides containing alternating D- and L-amino acids could self-assemble into nanotubes and can act as trans-membrane ion channels with comparable activity to naturally occurring cyclic peptide gramicidin A; paved way for design of self-assembling cyclic peptides. ${ }^{5}$ Since then formation of nanotubes and other structures such as nanorods, nanofibers, spherical structures from various cyclic peptides ${ }^{6}$ and their potential application had been reported thereof. ${ }^{7}$ In recent example by Ghadiri et al self-assembled nanotubes from cyclic peptides could block entry of Hepatitis $\mathrm{C}$ virus through cell membrane. ${ }^{8}$ In another report transport of antitumor drug through cyclic peptide nanotube was shown. ${ }^{9}$ Other important factors those contribute to design of cyclic peptides are their tunable ring size, control over hydrophobicity by altering amino acid side chains. ${ }^{6}$ Growing interest for transportation through cyclic peptide nanotubes had resulted in modifications of them with unnatural amino acids such as $\beta$-amino acids, alternating $\alpha$ - and $\beta$ amino acids, alternating $\alpha$ - and $\gamma$-amino acids, $\delta$-amino acids and carbohydrates, ${ }^{10}$ to have specific binding site at the interior of the nanotubes. ${ }^{7}$ Although having significant utilities, limitation of cyclic peptides arises from difficulty in their synthesis, low yield and requirement of expensive coupling reagents. ${ }^{1}$

Our group is concerned with the synthesis and design of various peptide based molecules for creation of nanostructured materials for applications such as drug delivery, multivalent receptors etc. ${ }^{11}$ In this regard, we are keen to synthesize cyclic peptides for studying self-assembly process as there is a heightened interest of such self-assembled materials in various disciplines due to their immense implication in both technological and medicinal field. Moreover, we also aim to functionalize the cyclic peptides post cyclization to incorporate some bioactive moieties in them which may enable in further enhancing their potential applications. Thus to contrive this aim, firstly, we choose to design a $\mathrm{C}_{2}$ symmetric cyclic hexapeptide cyclo(Gly-L-Ser-Gly) ${ }_{2}$ since it possess free $\mathrm{OH}$ groups which may enable further functionalization after cyclization. But contrary to our belief post modification of cyclo(Gly-L-Ser-Gly $)_{2}$ was a difficult and challenging task. Henceforth, we decided to modify the $\mathrm{OH}$ group prior to cyclization with propargyl group and subsequent cyclization lead to synthesis of cyclo[Gly-L-( $O$-propargyl)Ser-Gly $]_{2}$ which could afford conjugation of other molecule through aza-alkyne click reaction for specific applications. Herein, we report functionalization of mannose residues by conjugation to cyclic hexapeptide through click chemistry. The motivation for mannose functionalization originated from our previous studies where we demonstrated self-assembly of glycosylated dipeptides and its application in plasmid encapsulation and for studying its interaction with lectins. ${ }^{1 \mathrm{~h}-\mathrm{i}, 12}$ It is envisaged that glycosylation of peptides could not only induce self-assembling properties, but also alter morphology of soft structures in addition to conferring recognition properties. ${ }^{13}$ Selfassembly of this novel conjugate afforded very interesting morphological consequence since it afforded spherical morphologies instead of tubular structures formed by self-assembly of pristine cyclic hexapeptide itself. Mannose conjugation to cyclic peptide thus triggers stark change in morphology from tubular to spherical shape. 


\section{Results and Discussion}

For the synthesis of symmetric cyclic hexapeptide, two disconnection of the final compound is possible: i) macrocyclization after synthesis of linear hexapeptide, ii) selective cyclodimerization of linear tripeptide (Scheme 1). ${ }^{14}$ Cyclodimerization had been employed in some cases, but mostly cyclization steps involved disulfide bond formation, ${ }^{15}$ depsipeptide formation, ${ }^{16}$ click reaction to form triazole, ${ }^{17}$ unnatural amino acids, ${ }^{18}$ side chains (lysine, glutamic acid) of natural amino acids, ${ }^{14}$ metal ions as templates, ${ }^{19}$ and peptide containing thiazole ring in side chain. ${ }^{20}$

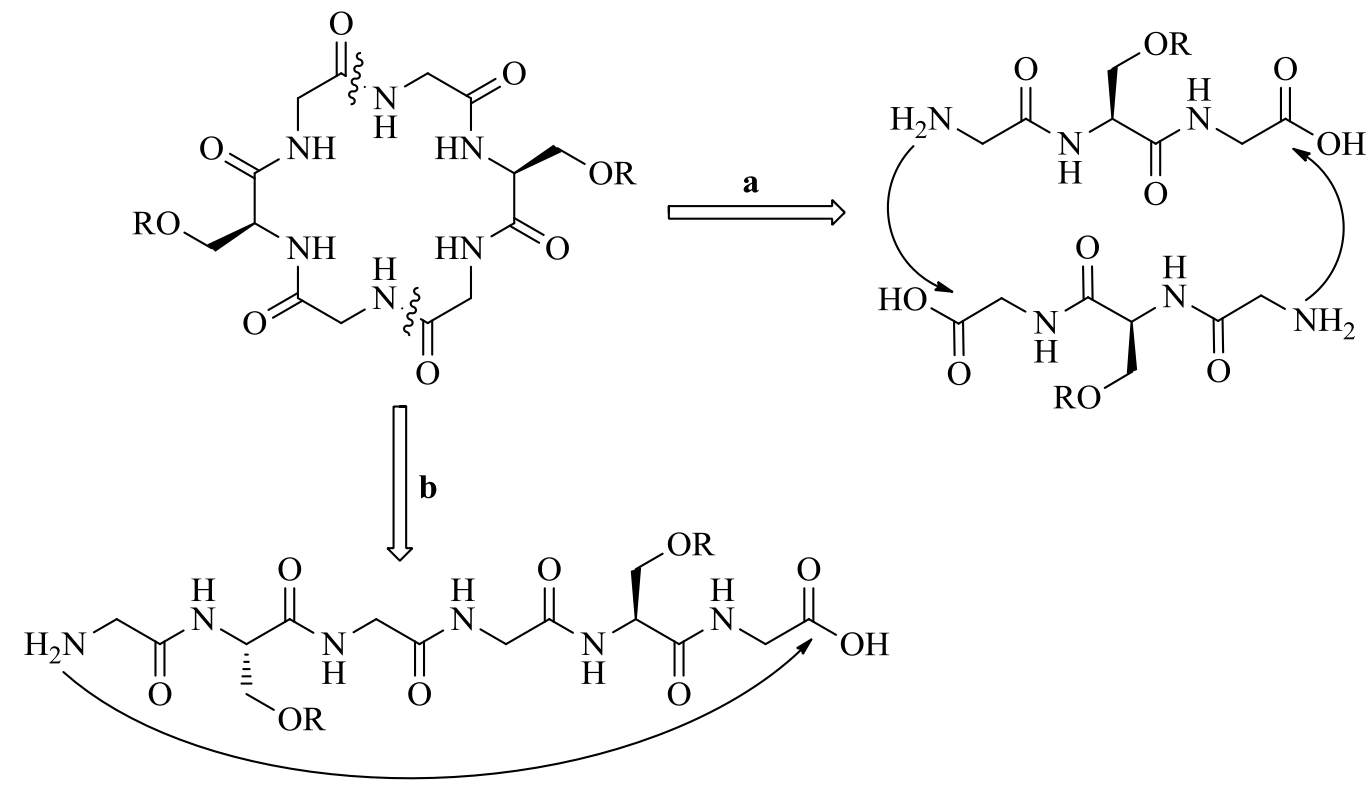

Scheme 1. Disconnection approach for synthesis of symmetric hexapeptides.

Since our target peptides were rich in glycine, a $\beta$-turn inducer, ${ }^{2}$ we chose the cyclodimerization route (Scheme1, route a), instead of cyclization of a linear hexapeptide (Scheme1, route b) for imparting enhanced synthetic feasibility and avoiding unnecessary synthetic and purification steps. We were also motivated by our previous work, in which a proline-containing symmetric cyclic hexapeptide was synthesized by cyclodimerisation. ${ }^{11 \mathrm{~g}, \mathrm{f}}$ In that case the presence of proline further increased the possibility of cyclodimerization.

Linear tripeptides (4 and 10) were synthesized using standard solution phase peptide synthetic methods with dicyclohexylcarbodiimide (DCC) and 1-hydroxybenzotriazole (HOBt) as coupling reagents (Scheme 2,3). The tripeptides were then activated by synthesizing $\mathrm{p}$ nitrophenol esters using DCC as coupling reagent. Cleavage of amine protecting group was accomplished by treatment with trifluoroacetic acid (TFA). At this stage the amine groups are not reactive due to their presence in salt form. 
<smiles>COCC(N)C(=O)OC</smiles>

1

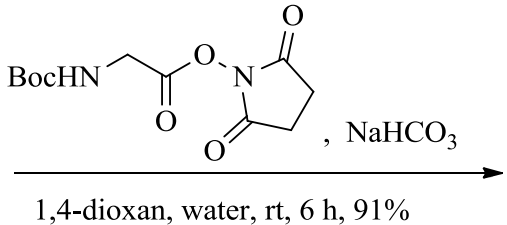

1,4-dioxan, water, rt, $6 \mathrm{~h}, 91 \%$

$\prod_{\mathrm{O}}^{\mathrm{OCPh}}$

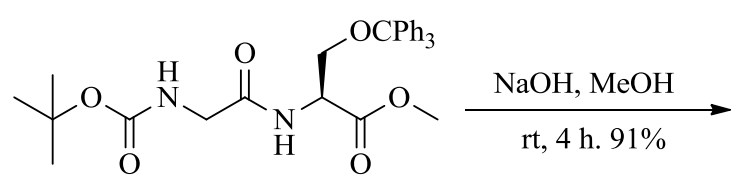

2

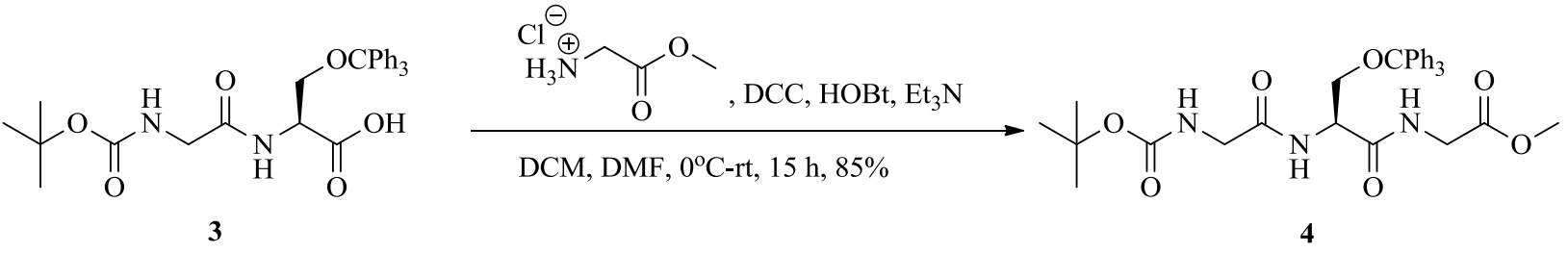

Scheme 2. Synthetic methodology for tripeptide Boc-Gly-L-( $O$-trityl)Ser-Gly-OMe (4).

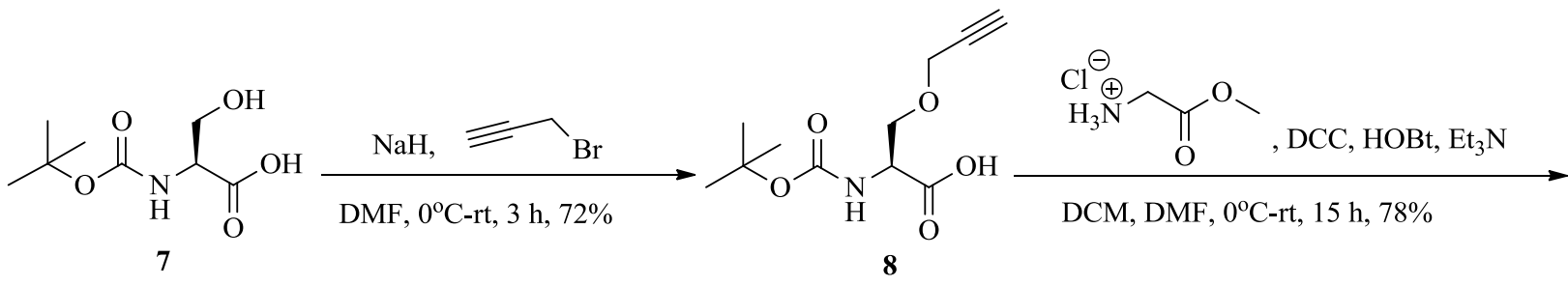<smiles>C#CCOC[C@H](NC(=O)OC(C)(C)C)C(=O)NCC(=O)OC</smiles>

9

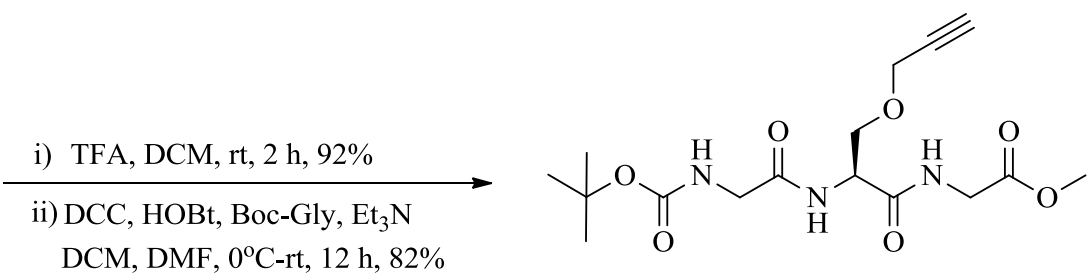

10

Scheme 3. Synthetic methodology for tripeptide Boc-Gly-L-( $O$-propargyl)Ser-Gly-OMe (10). 1, Boc-Gly-ONHS and $\mathbf{8}$ was synthesized following earlier reports. ${ }^{21}$

A propargyl group was incorporated in $\mathbf{1 0}$ with the aim to derivatize the cyclic peptide post cyclization using click chemistry. Cyclizations were carried out by dropwise addition of deprotected active ester solutions in DMF at room temperature into a solution of triethylamine in DMF (Scheme 4). 4-5 drops were allowed to fall per minute and the whole solution was added over 3-4 h. Dropwise addition maintained very dilute concentrations of the reactants $(3-4 \mu \mathrm{mol})$, favoring cyclodimerization over oligomerization. Conjugation of mannose with cyclic hexapeptide 13 using aza-alkyne click reaction also became feasible by incorporation of propargyl group prior to cyclization. Thus, tetracetylmannose azide was conjugated to cyclic hexapeptide resulting in formation of conjugate $\mathbf{1 4}$ which was purified by silica gel column chromatography purification (Scheme 5). Characterization by ${ }^{1} \mathrm{H},{ }^{13} \mathrm{C}$ NMR spectroscopy, high 
resolution mass spectroscopy and X-ray crystallography confirmed synthesis of $\mathbf{6}$ and $\mathbf{1 5}$ in accordance with molecular structures. Yield of cyclization were moderate but we were able to achieve it in solution phase without using any expensive coupling reagent or sophisticated experimental set up. Since synthesis of $\mathbf{6}$ and $\mathbf{1 3}$ were accomplished with similar yields it could also be inferred that a substituent at the Ser residue did not affect the reaction process.

ii) DCC, p-nitrophenol, DCM $0^{\circ} \mathrm{C}-\mathrm{rt}, 5 \mathrm{~h}, 84 \%$<smiles>CCOC[C@H](NC(=O)CNC(=O)OC(C)(C)C)C(=O)NCC(=O)Oc1ccc([N+](=O)[O-])cc1</smiles>

i) TFA, DCM, rt, $2 \mathrm{~h}$

ii) $\mathrm{Et}_{3} \mathrm{~N}, \mathrm{DMF}, \mathrm{rt}, 20 \mathrm{~h}, 41 \%$<smiles></smiles>

6

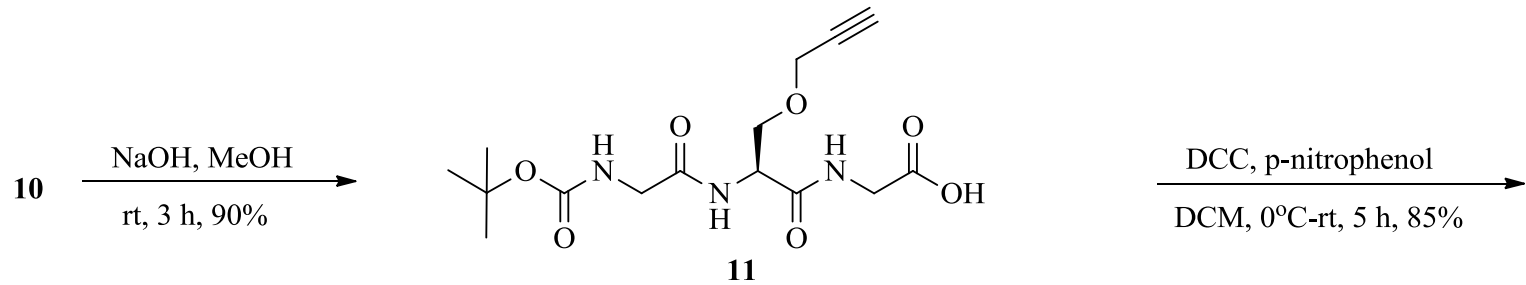<smiles>C#CCOCC(NC(=O)CNC(=O)CNC(=O)C(COCC#C)NC(=O)CNC(=O)OC(C)(C)C)C(=O)NCC(=O)NCC(=O)NC(COCC#C)C(=O)NCC(=O)Oc1ccc([N+](=O)[O-])cc1</smiles>

13

Scheme 4. Synthetic methodology for cyclic hexapeptides cyclo(Gly-L-Ser-Gly $)_{2}(6)$ and cyclo[Gly-L-( $O$-propargyl)Ser-Gly $]_{2}(\mathbf{1 3})$. 


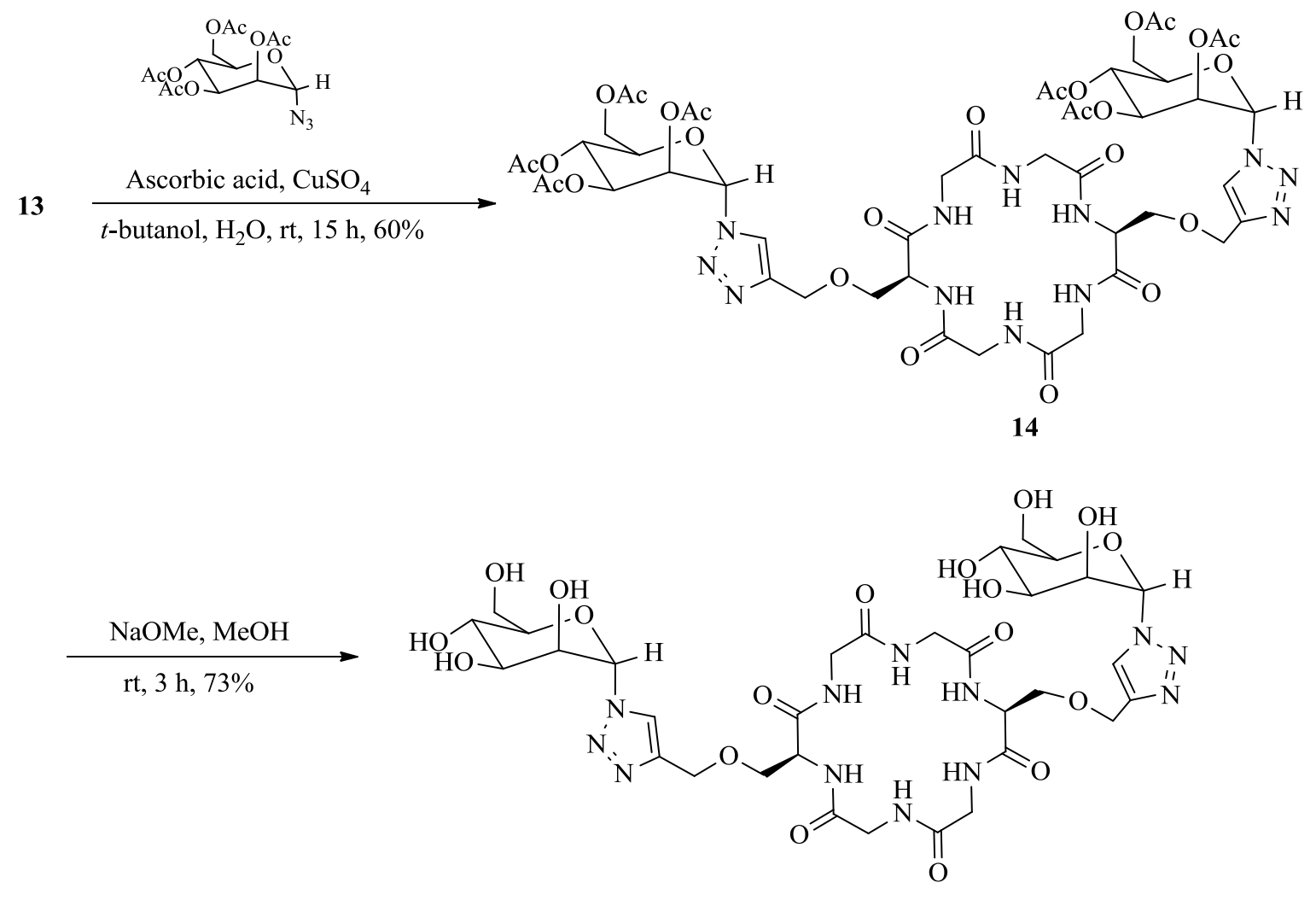

15

Scheme 5. Synthetic methodology for conjugation of mannose with cyclo[Gly-L- $(O$ propargyl)Ser-Gly $]_{2}$. Tetracetylmannose azide was prepared according to previous reports. ${ }^{22}$

Crystal studies further support formation of $\mathbf{6}$ via cyclodimerization. $\mathbf{6}$ was dissolved in hot water and kept for slow evaporation. Needle-like crystals formed after 7 days. 6 crystallized in space group P 21/n. The role of the hydroxyl group of Ser was found to be crucial in stabilizing the solid state structure. Along the b-axis the cyclic peptides stack with each other to form columnar structure supported by intermolecular $\mathrm{H}$-bonding through $\mathrm{OH}$ of Ser side chain acting both as donor to carbonyl oxygen $(\mathrm{O} 4-\mathrm{H} \cdots \mathrm{O} 1,1.92 \AA)$ and acceptor to amide NH (N9-H...O4, $1.95 \AA$ A (Figure 1a). Further, these 2D stacked layer of cyclic peptides grow in 3D by support $\mathrm{H}$ bonding through water molecules. Two water molecules form two H-bonds with carbonyl oxygen as donor $(\mathrm{OW}-\mathrm{H} \cdots \mathrm{O} 3,1.91 \AA)$ and accept amide protons of the same molecule of cyclic peptide to from two other H-bonds (N3-H…OW, $2.06 \AA$ ). The water molecules then connect other two cyclic peptides in two directions through $\mathrm{H}$-bonding between carbonyl and $\mathrm{OH}$ of water (OW-H...O2, $1.98 \AA$ ) (Figure 2).

Cyclic peptides are known to self-assemble in ordered nanostructures, notably to nanotubes in solution phase. In our previous report, we have shown that $\mathbf{6}$ self-assembled into nanofibers in 1:1 methanol: water upon prolonged ageing. ${ }^{11 \mathrm{e}} \mathrm{We}$ studied the self-assembly process of $6(1 \mathrm{mM}$ in water) using different microscopic techniques. AFM images taken on both glass surface and silicon wafer showed formation of micrometer long fibrillar structures (Figure 3a,b). Optical 
microscopy image also confirmed formation of fibers (Figure 3c). Stacking of cyclic peptide molecules one above another by intermolecular complementary H-bonding of amide functionality facilitates formation of nanotubes in case of cyclic peptides ${ }^{5}$. From the crystal structure we could propose that formation of nanotubes from $6^{11 \mathrm{e}}$ also formed by stacking of cyclic peptide molecules with each other, but stabilization in this case is not by backbone $\mathrm{H}$ bonding between amide bonds; rather it was assisted by the hydroxyl groups of Ser side chains and water molecules (Figures 1a, 2).

a

$c \stackrel{b}{\longrightarrow} a$

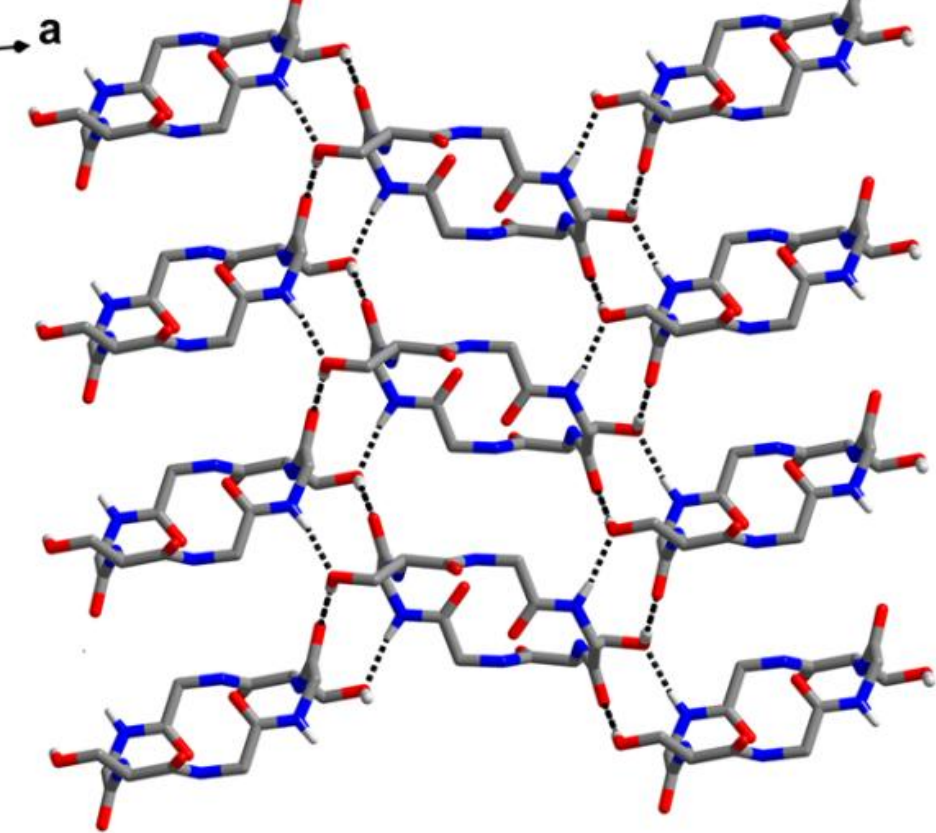

b<smiles>CCC(NC(=O)CNC(=O)CNC(=O)C(CO)NC(=O)C(C)NC(=O)CNC(=O)O)C(=O)O</smiles>

C

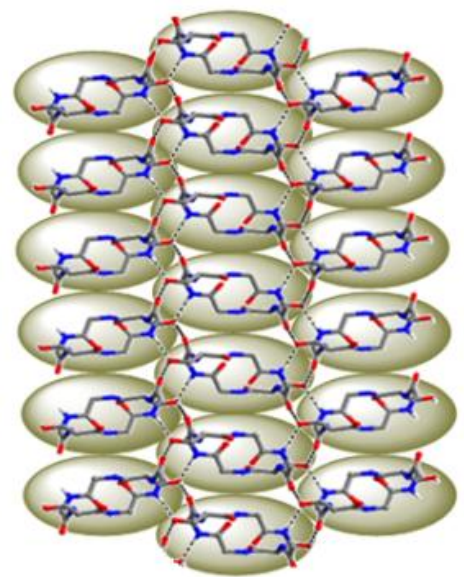

Figure 1. (a) Stacking of molecules of $\mathbf{6}$ through H-bonding assisted by hydroxyl group of Ser side chain. (b) Numbering scheme for 6. (c) Diagrammatic representations for stacking interactions in $\mathbf{6}$ to form nanotubular structure.

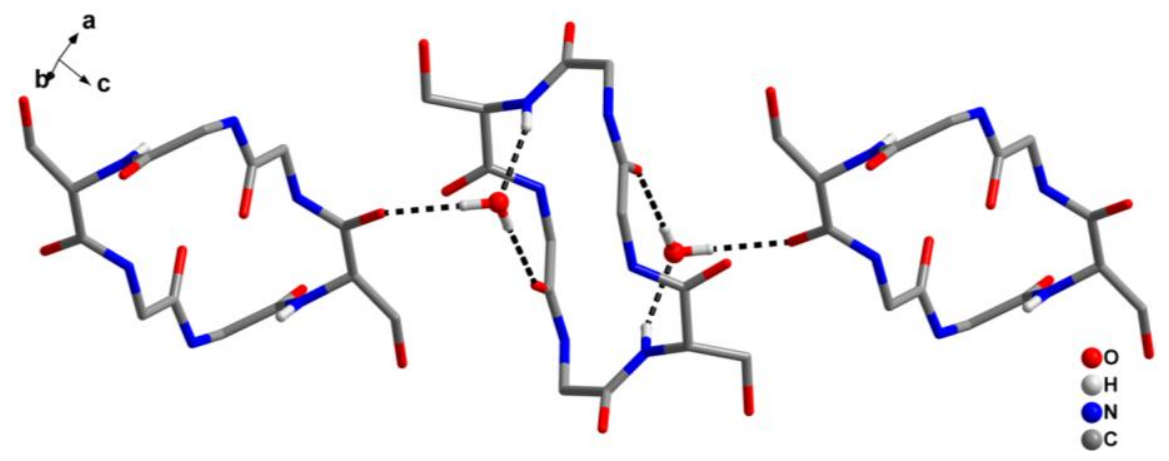

Figure 2. Water assisted interconnection of cyclic peptide molecules. 
We studied the self-assembly process of glycopeptide conjugate $\mathbf{1 5}$ in aqueous solvents with the help of microscopy techniques. $1 \mathrm{mM}$ solutions of $\mathbf{1 5}$ were incubated in methanol: water (1:1) and water for different time intervals at room temperature. Atomic force microscopy (AFM) study on silicon surface revealed formation of spherical morphology with diameter of about $600 \mathrm{~nm}$ in both cases (Figure 4). Morphology of the self-assembled structures did not changed with time as could be seen from images of 1 day and 7 days aged samples. Further, clustered aggregates of spherical morphology were also observed in scanning electron microscopy (SEM) for 15 (1 mM in methanol: water, 1:1) at different times of ageing (Figure 5) confirming the solution phase self-assembling behavior of $\mathbf{1 5}$ to spherical shape.

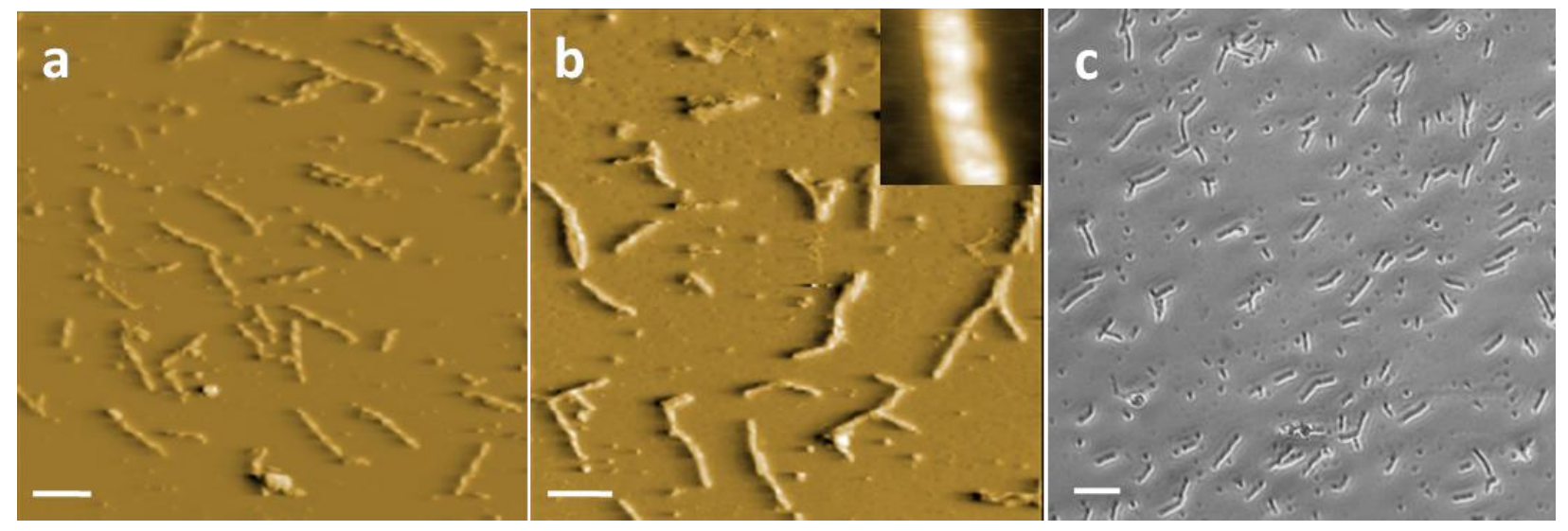

Figure 3. AFM images of $1 \mathrm{mM} 6$ in water on (a) glass \& (b) silicon wafer after 7 days ageing; inset shows magnified image of a fiber. c) Optical microscopy image of 7 days aged sample. Scale bar $10 \mu \mathrm{m}$.
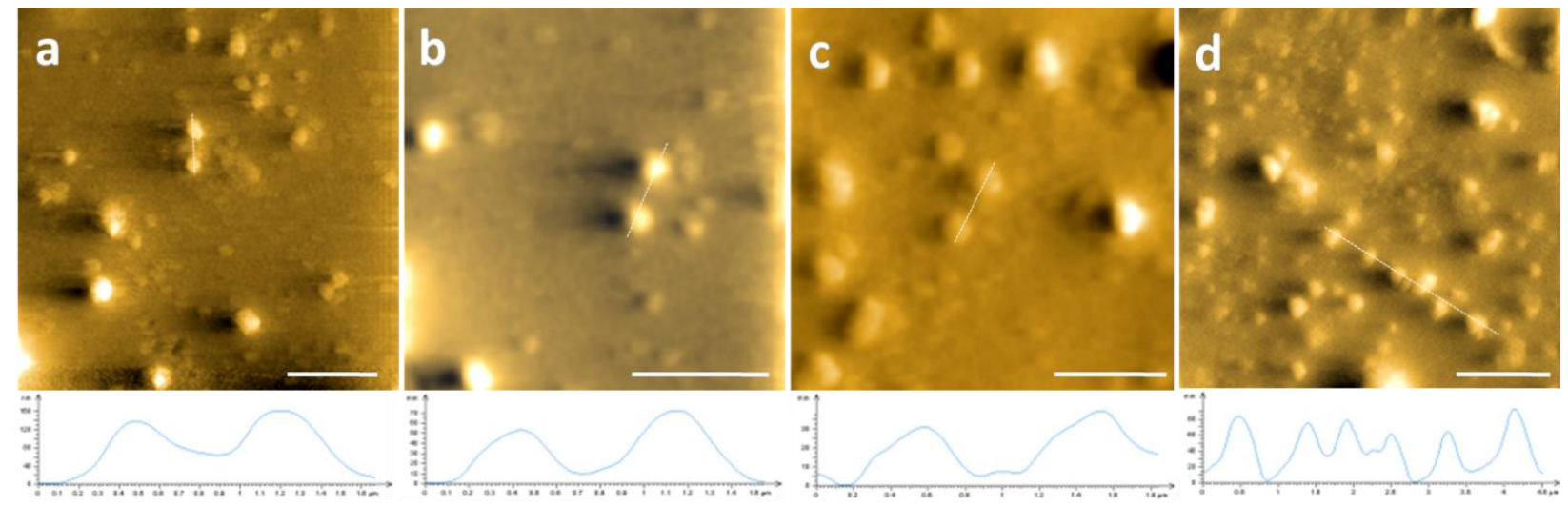

Figure 4. AFM images of $1 \mathrm{mM} 15$ in 1:1 methanol: water on silicon surface: (a) 1 day (c) 7 day and in water (b) 1 day (d) 7 days. Height profiles are shown below each image. Scale bar $2 \mu \mathrm{m}$. 

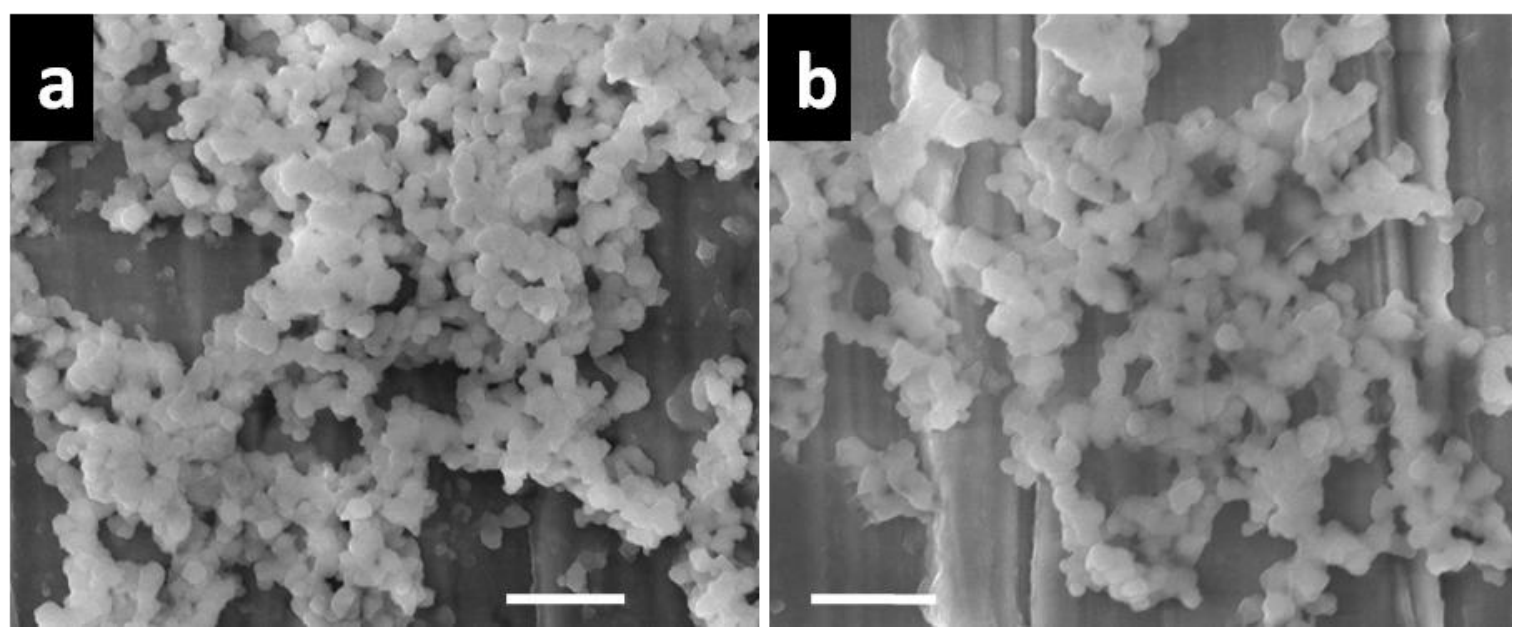

Figure 5. SEM images of $1 \mathrm{mM} 15$ in 1:1 methanol: water on $\mathrm{Cu}$ stub: (a) 1 day (c) 7 days. Scale bar $1 \mu \mathrm{m}$.

Moreover, from the structures of $\mathbf{6}$ and 15, it could be assessed that the change in substituent at the serine residues of $\mathbf{1 5}$ is directing the change in self-assembled morphology from tubular structure of 6 to spherical structure of 15. Such substituent dependent morphology of cyclic peptides were recently shown by Zhang et al. where they observed that by changing substituent present in a synthetic cyclic peptide could alter its self-assembly from nano-fibrillar to nanospherical structures. ${ }^{6 \mathrm{~b}}$ A recent report by Gianneschi and coworkers demonstrated the crucial role of hydrophobic to hydrophilic balance in inducing morphological changes from micellar to cylindrical shape. ${ }^{23}$ In our recent report, we had also shown that conjugation of mannose to diphenylalanine dipeptide exerted morphological changes depending upon number of mannose residues due to increased hydrophilic character. ${ }^{11 \mathrm{~h}}$ Also we observed in the crystal structure that the presence of the hydroxyl group of Ser side-chain is critical in stabilization of stacking of cyclic peptide 6. Thus, we surmise that possibly substitution at Ser $\mathrm{OH}$ and presence of hydrophilic mannose groups in $\mathbf{1 5}$, as compared to $\mathbf{6}$, might lead to a different H-bonding pattern resulting in transition of self-assembled morphologies from tubular to spherical shape.

\section{Conclusions}

We synthesized two glycine rich cyclic hexapeptides in solution phase employing cyclodimerization as the macrocyclization step with moderate yields. The cyclization was achieved without using any expensive coupling reagents. Conjugation of mannose to one of the cyclic peptide was done through aza-alkyne click reaction. Conjugation of mannose induces a dramatic shift from tubular morphology of pristine cyclic hexapeptide to spherical shape. These results are very interesting and open new avenues for post synthetic modification methodologies and also controlled manipulation of morphological consequences of self-assembled structures. 
Our future endeavors will include a further study of the potential of these morphologies as delivery vehicles. Facile modification of cyclic peptide with mannose residue via aza-alkyne reaction motivates us to further use this methodology for functionalizing cyclic peptide with bioactive moieties to yield novel conjugates of immense potential for applications in biomedicine and tissue engineering for instance.

\section{Experimental Section}

General. Dichloromethane, $N, N$-dimethylformamide, triethylamine were distilled following standard procedures prior to use. Dicyclohexylcarbodiimide (DCC), 1-hydroxybenzotriazole (HOBt), N-hydroxysuccinimide (NHS), glycine L-serine, trityl chloride, TFA were purchased from Spectrochem Pvt. Ltd.; mannose, ascorbic acid were obtained from Sisco Research laboratories Pvt. Ltd.; p-nitrophenol, copper sulphate, triethylsilane were purchased from S.d. Fine-chem limited, Mumbai and used without further purification. Propargyl bromide was purchased from Alfa Aesar, Massachusetts, USA. ${ }^{1} \mathrm{H}$ and ${ }^{13} \mathrm{C}$ NMR spectra were recorded on JEOL ECX-500 model operating at 500 and $125 \mathrm{MHz}$, respectively. HRMS mass spectra were recorded on a Micromass Quattro II triple quadrapole mass spectrometer employing capillary voltage of $2.6-3.2 \mathrm{kV}$.

\section{Microscopic techniques}

Optical microscopy. $10 \mu \mathrm{L}$ solution of 6 (1 mM in water) was spread on a glass slide, dried at room temperature, and imaged under fluorescence microscope (Leica DM2500M) using 40× lens.

Atomic force microscopy (AFM). Atomic force microscopy was carried out in air using an Agilent Technologies AFM (5500 AFM/SPM) operating under the Acoustic AC mode (AAC). The sample was mounted on the XY stage of the AFM and the integral video camera (NAVITAR, Model N9451A-USO6310233) with the Fibre-light source, MI-150 high intensity illuminator from Dolan-Jenner Industries) was used to locate the regions of interest. Silicon nitride cantilevers with resonant frequency of $150 \mathrm{kHz}$ were used. The average dimension thickness, width and length of cantilever were approximately 2.0, 51 and $446 \mu \mathrm{m}$, respectively. The scanner model N9524A-USO7480132.xml/N9520A-USO7480152.xml was calibrated and used for imaging. The images were taken in air at room temperature, with the scan speed of 1.52.2 lines/sec. Data acquisition and analysis was carried out using Pico View ${ }^{\circledR} 1.8$ Basic software, respectively. $10 \mu \mathrm{L}$ aliquot of solutions of 6 and $\mathbf{1 5}$ were deposited on onto silicon wafer at room temperature. The sample-coated silicon surfaces were dried in air at room temperature for $2 \mathrm{~h}$, followed by AFM imaging.

Scanning electron microscopy (SEM). Field emission scanning electron microscopy images acquired on Supra 40 VP SEM (Zeiss, Germany), equipped with a tungsten filament gun, operating at WD $10.6 \mathrm{~mm}$ and $20 \mathrm{kV} .10 \mu \mathrm{L}$ aliquots of the fresh and aged solutions of 15 were 
placed on silicon wafer. The samples were dried at room temperature for $2 \mathrm{~h}$ and then vacuum dried for another 30 minutes. The dried samples were then gold coated and imaged in FE-SEM.

\section{Synthetic procedures and characterization}

Boc-Gly-L-( $\boldsymbol{O}$-trityl)Ser-OMe (2). L- $\left(O\right.$-trityl)Ser-OMe ${ }^{21 \mathrm{a}}(1.6 \mathrm{~g}, 4.4 \mathrm{mmol})$ was taken in a round bottom flask and dissolved in 1,4-dioxan. To this aqueous sodium bicarbonate $(0.74 \mathrm{~g}, 8.8$ mmol) solution was added to make the solution $\mathrm{pH}$ around 8.0. To this basic solution Boc-GlyONHS $^{21 \mathrm{~b}}(1.2 \mathrm{~g}, 4.4 \mathrm{mmol})$ was added and reaction is stirred for $6 \mathrm{~h}$. Then solvent was evaporated to dryness under vacuum and the residue was dissolved in DCM (150 mL) followed by the washing with $1 \mathrm{~N} \mathrm{HCl}(2 \times 100 \mathrm{~mL}), 10 \%$ aqueous sodium bicarbonate $(2 \times 100 \mathrm{~mL})$ solution and brine solution $(100 \mathrm{~mL})$ respectively. The combined organic layer was dried over anhydrous sodium sulphate. The crude product was purified by silica gel column chromatography with solvent system DCM/MeOH (98:2). Yield $2.04 \mathrm{~g}$, (91\%). R $\mathrm{R}_{\mathrm{f}} 0.6$ (5\% $\mathrm{MeOH} / \mathrm{DCM}) .{ }^{1} \mathrm{H}$ NMR (500 MHz, $\mathrm{CDCl}_{3}, 25^{\circ} \mathrm{C}, \mathrm{TMS}$ ) $\delta(\mathrm{ppm}): 1.40\left(9 \mathrm{H}, \mathrm{s}, \mathrm{CH}_{3} \mathrm{Boc}\right), 3.34-$ $3.36\left(1 \mathrm{H}, \mathrm{d}, J 2.9 \mathrm{~Hz}, 9.2 \mathrm{~Hz},-\mathrm{CH}_{2}\right), 3.59-3.61\left(1 \mathrm{H}, \mathrm{dd}, J 2.6 \mathrm{~Hz}, 8.9 \mathrm{~Hz}, \mathrm{CH}_{2}\right), 3.72-3.77(4 \mathrm{H}$, $\left.\mathrm{m},-\mathrm{OCH}_{3},-\mathrm{CH}_{2}\right), 3.82-3.90\left(1 \mathrm{H}, \mathrm{m},-\mathrm{CH}_{2}\right), 4.67-4.70(1 \mathrm{H}, \mathrm{m},-\mathrm{CH} \mathrm{Ser}), 5.10(1 \mathrm{H}, \mathrm{s}, \mathrm{brd}, \mathrm{NH}$ Boc), 6.88 (1H, s, brd, NH amide), 7.21-7.27 (m, 3H, trityl), 7.29-7.31 (6H, m, trityl), 7.34-7.37 (6H, m, trityl). ${ }^{13} \mathrm{C} \mathrm{NMR} \mathrm{(125} \mathrm{MHz,} \mathrm{CDCl}_{3}, 25^{\circ} \mathrm{C}, \mathrm{TMS}$ ) $\delta$ (ppm): 28.4, 44.4, 52.3, 54.4, 62.9, $80.8,82.0,127.3,128.0,129.8,146.9,156.5,169.9,170.9$. ESI-HRMS: $m / z$ for $[\mathrm{M}+\mathrm{H}]^{+}$ Calculated $\left(\mathrm{C}_{30} \mathrm{H}_{35} \mathrm{~N}_{2} \mathrm{O}_{6}\right)$ 519.2495, found 519.2493.

Boc-Gly-L-(O-trityl)Ser-OH (3). 2 (1.96 g, $3.6 \mathrm{mmol})$ was dissolved in minimum volume of methanol and to it $1 \mathrm{~N}$ sodium hydroxide $(0.3 \mathrm{~g}, 7.2 \mathrm{mmol})$ dissolved in $7.5 \mathrm{~mL}$ of distilled water solution was added and stirred for $4 \mathrm{~h}$. The solvent was then passed through cation exchange resin. The eluent was evaporated under vacuum. Yield $1.8 \mathrm{~g},(91 \%) .{ }^{1} \mathrm{H} \mathrm{NMR}(500 \mathrm{MHz}$, $\mathrm{CD}_{3} \mathrm{OD}, 25^{\circ} \mathrm{C}, \mathrm{TMS}$ ) $\delta(\mathrm{ppm}): 1.38\left(9 \mathrm{H}, \mathrm{s},-\mathrm{CH}_{3} \mathrm{Boc}\right), 3.33-3.35$ (1H, dd, J $2.85 \mathrm{~Hz}, 10.3 \mathrm{~Hz}$, $\mathrm{CH}_{2}$ Ser $), 3.52-3.54\left(1 \mathrm{H}, \mathrm{dd}, J 2.85 \mathrm{~Hz}, 8.6 \mathrm{~Hz},-\mathrm{CH}_{2} \mathrm{Ser}\right), 3.68-3.72\left(1 \mathrm{H}, \mathrm{d}, J 17.2 \mathrm{~Hz},-\mathrm{CH}_{2}\right.$ Gly), 3.78-3.82 (1H, d, J 17.15 Hz, - $\mathrm{CH}_{2}$ Gly), $4.56(1 \mathrm{H}, \mathrm{s}$, brd, -CH Ser), 7.20-7.23 (3H, m, trityl), 7.27-7.30 $(6 \mathrm{H}, \mathrm{t}, J 7.45 \mathrm{~Hz}$, trityl $), 7.39-7.40\left(6 \mathrm{H}, \mathrm{d}, J 6.85 \mathrm{~Hz}\right.$, trityl). ${ }^{13} \mathrm{C}$ NMR $(125$ $\mathrm{MHz}, \mathrm{CD}_{3} \mathrm{OD}, 25{ }^{\circ} \mathrm{C}, \mathrm{TMS}$ ) $\delta$ (ppm): 27.4, 43.4, 52.8, 63.3, 79.5, 86.5, 126.8, 127.5, 128.4, 143.6, 157.0, 170.9, 171.9. ESI-HRMS: $m / z$ for $[\mathrm{M}+\mathrm{H}]^{+}$Calculated $\left(\mathrm{C}_{29} \mathrm{H}_{33} \mathrm{~N}_{2} \mathrm{O}_{6}\right)$ 505.2339, found 505.2336.

Boc-Gly-L-( $O$-trityl)Ser-Gly-OMe (4). 3 (1.8 g, $3.56 \mathrm{mmol})$ and 1-hydroxybenzotriazole (600 $\mathrm{mg}, 3.91 \mathrm{mmol})$ were dissolved in dry DCM $(20 \mathrm{~mL})$ and DMF $(10 \mathrm{~mL})$ and reaction mixture was cooled to $0^{\circ} \mathrm{C}$ under nitrogen atmosphere. Solution of DCC $(0.8 \mathrm{~g}, 3.9 \mathrm{mmol})$ in DCM (5 $\mathrm{mL}$ ) was added into the reaction mixture at $0^{\circ} \mathrm{C}$ under nitrogen atmosphere. The reaction mixture was further stirred at $0^{\circ} \mathrm{C}$ for half an hour. Hydrochloride salt of glycine methylester (490 mg, $3.9 \mathrm{mmol}$ ) was then added into the reaction mixture followed by addition of triethylamine (1.1 $\mathrm{mL}, 7.8 \mathrm{mmol}$ ) and stirring was continued for $15 \mathrm{~h}$ at room temperature. Next, the reaction mixture was filtered to remove $N, N^{\prime}$-dicyclohexylurea and filtrate was concentrated in reduced pressure. The residue was dissolved in ethyl acetate and organic layer was washed with aqueous 
$1 \mathrm{~N} \mathrm{HCl}$ and $10 \%$ aqueous $\mathrm{NaHCO}_{3}$ solution. The organic layer was then dried over anhydrous sodium sulphate and concentrated under reduced pressure. The crude compound was purified through a silica gel column chromatography by using DCM/MeOH $(98: 2)$ as solvent system to give pure compound as white solid. Yield $1.75 \mathrm{~g},(85 \%) . \mathrm{R}_{\mathrm{f}} 0.7(10 \% \mathrm{MeOH} / \mathrm{DCM}) .[\alpha]_{\mathrm{D}}{ }^{25}{ }_{+}$ 9.35 (c 0.39, $\left.\mathrm{CH}_{3} \mathrm{OH}\right) .{ }^{1} \mathrm{H} \mathrm{NMR}\left(500 \mathrm{MHz}^{\circ} \mathrm{CDCl}_{3}\right): 1.42\left(9 \mathrm{H}, \mathrm{s},-\mathrm{CH}_{3} \mathrm{Boc}\right), 3.66-3.70(2 \mathrm{H}, \mathrm{m}$, $\left.-\mathrm{CH}_{2} \mathrm{Ser}\right), 3.72\left(3 \mathrm{H}, \mathrm{s},-\mathrm{OCH}_{3}\right), 3.81\left(2 \mathrm{H}, \mathrm{s},-\mathrm{CH}_{2} \mathrm{Gly}\right), 4.09-4.11$ (2H, d, J $\left.11.75 \mathrm{~Hz},-\mathrm{CH}_{2} \mathrm{Gly}\right)$, 4.51-4.54 (1H, m, -CH Ser), 5.40 (1H, s, brd, NH Boc amide), 7.22-7.32 (15H, m, trityl), 7.40$7.41\left(1 \mathrm{H}, \mathrm{d}, J 7.7 \mathrm{~Hz},-\mathrm{NH}\right.$ amide) $7.48\left(1 \mathrm{H}, \mathrm{s}, \mathrm{brd},-\mathrm{NH}\right.$ amide). ${ }^{13} \mathrm{C} \mathrm{NMR}\left(125 \mathrm{MHz}, \mathrm{CDCl}_{3}, 25\right.$ $\left.{ }^{\circ} \mathrm{C}, \mathrm{TMS}\right) \delta(\mathrm{ppm}):$ 28.3, 41.3, 44.5, 52.6, 54.6, 62.7, 80.8, 82.1, 127.3, 128.0, 128.5, 146.9, 156.7, 170.5, 170.7, 171.3. ESI-HRMS: $\mathrm{m} / z$ for $[\mathrm{M}+\mathrm{H}]^{+}$Calculated $\left(\mathrm{C}_{32} \mathrm{H}_{38} \mathrm{~N}_{3} \mathrm{O}_{7}\right) 576.2710$, found 576.2714 .

Boc-Gly-L-(O-trityl)Ser-Gly-OPNP (5). 4 (1.75 g, $3.12 \mathrm{mmol})$ was dissolved in $20 \mathrm{~mL}$ methanol and to it aqueous $1 \mathrm{~N}$ sodium hydroxide $(3.43 \mathrm{~mL})$ solution was added and stirred for four hours. The solvent was passed through cation exchange resin. The eluent was evaporated to get Boc-Gly-L-(O-trityl)Ser-Gly-OH as white solid product. Yield $1.53 \mathrm{~g}(90 \%) \mathrm{R}_{\mathrm{f}} .0 .3(10 \%$ methanol/ DCM) This was used without further analysis in next step.

Boc-Gly-L-( $O$-trityl)Ser-Gly-OH (1.5 g, $2.67 \mathrm{mmol})$ and p-nitrophenol (0.41 g, $2.94 \mathrm{mmol})$ was dissolved in $15 \mathrm{~mL}$ dry DCM. The solution was cooled to $0^{\circ} \mathrm{C}$ in an ice bath. To it DCC (606 $\mathrm{mg}, 2.94 \mathrm{mmol}$ ) (dissolved in $5 \mathrm{~mL}$ dry DCM) was added and the stirring was continued for 30 min in ice cold condition. The reaction mixture was then further stirred for $6 \mathrm{~h}$ at room temperature. The white precipitate of N, N'-dicyclohexylurea was filtered off. The organic layer was washed with $5 \%$ sodium bicarbonate solution $(4 \times 40 \mathrm{~mL})$ and brine $(40 \mathrm{~mL})$. DCM was evaporated and the residue was washed with pentane to give pure product as light yellow solid. $\mathrm{R}_{\mathrm{f} .} 0.6(5 \% \mathrm{MeOH} / \mathrm{DCM})$. Yield $1.53 \mathrm{~g}(84 \%) .[\alpha]_{\mathrm{D}}{ }^{25} .+1.81^{\circ}\left(c 0.27, \mathrm{CH}_{3} \mathrm{OH}\right) .{ }^{1} \mathrm{H}$ NMR (500 $\mathrm{MHz}, \mathrm{CDCl}_{3}, 25^{\circ} \mathrm{C}, \mathrm{TMS}$ ) $\delta(\mathrm{ppm}) 1.44\left(9 \mathrm{H}, \mathrm{s},-\mathrm{CH}_{3}\right.$ Boc), 3.67-3.70 (1H, dd, J 4.9 Hz, 11.75 $\left.\mathrm{Hz},-\mathrm{CH}_{2} \mathrm{Ser}\right), 3.79-3.80\left(2 \mathrm{H}, \mathrm{d}, J 5.15 \mathrm{~Hz},-\mathrm{CH}_{2} \mathrm{Gly}\right), 4.11-4.22\left(2 \mathrm{H}, \mathrm{m},-\mathrm{CH}_{2}\right), 4.32-4.36(1 \mathrm{H}$, m, $\left.-\mathrm{CH}_{2}\right), 4.55-4.57(1 \mathrm{H}, \mathrm{m}, \mathrm{CH}$ Ser $), 5.39$ (1H, s, brd, -NH amide Boc), 7.22-7.32 (15H, m, trityl), 7.39-7.40 (2H, d, J 7.45 Hz, aromatic -CH PNP), 7.75 (1H, s, brd, -NH amide), 8.23-8.25 $\left(2 \mathrm{H}, \mathrm{d}, J 9.15 \mathrm{~Hz}\right.$, aromatic -CH PNP). ${ }^{13} \mathrm{C} \mathrm{NMR}\left(125 \mathrm{MHz}, \mathrm{CDCl}_{3}, 25{ }^{\circ} \mathrm{C}, \mathrm{TMS}\right.$ ) $\delta(\mathrm{ppm}) 28.4$, 41.6, 44.7, 54.5, 62.4, 81.0, 82.1, 122.3, 125.4, 127.4, 128.0, 129.8, 145.6, 146.9, 155.0, 156.8, 167.9, 170.5, 172.6. ESI-HRMS: $m / z$ for $[\mathrm{M}+\mathrm{H}]^{+}$Calculated $\left(\mathrm{C}_{37} \mathrm{H}_{39} \mathrm{~N}_{4} \mathrm{O}_{9}\right)$ 683.2717, found 683.2732.

Cyclo(Gly-L-Ser-Gly)2 (6). 5 (1.5 g, $2.19 \mathrm{mmol})$ was dissolved in $4 \mathrm{~mL}$ DCM. Triethylsilane $(0.34 \mathrm{~mL}, 2.19 \mathrm{mmol})$ was added to this solution followed by addition of $4 \mathrm{~mL}$ trifluroacetic acid. The reaction mixture was stirred for additional $2 \mathrm{~h}$ at room temperature. The solvent was then evaporated; the gummy residue was washed with diethyl ether $(4 \times 10 \mathrm{~mL})$ times to remove triphenylmethane and other impurities. Finally the white solid product was dried in vacuum and used for next step immediately. $\mathrm{R}_{\mathrm{f} .} 0.2$ (10\% MeOH/DCM). Triethylamine (1.23 mL, $\left.8.76 \mathrm{mmol}\right)$ was dissolved in dry DMF $(120 \mathrm{~mL})$ in a two necked RB flask. To solution of TFA.glycine- $O$ trityl-serine-glycine-para nitro phenol ester in dry DMF $(30 \mathrm{~mL})$ was added slowly with the help 
of dropping funnel at rate of about 4 drops per minute over a period of $4 \mathrm{~h}$ with constant stirring under nitrogen atmosphere. The color of the solution turned yellow as the reaction progresses. The reaction was then stirred overnight. DMF was evaporated and the residue was washed with diethyl ether $(3 \times 20 \mathrm{~mL})$ and acetone $(3 \times 10 \mathrm{~mL})$ to get a brownish solid product. TLC was monitored to see complete removal of $p$-nitrophenol and other UV active spots. Finally the solid was treated with methanol $(10 \mathrm{~mL})$ and centrifuged. The supernatant solution was decanted and the solid was further was with methanol for 2 more times. The compound was then dried in vacuum to give pure compound as white solid. Yield.180 mg (41\%). [ $\alpha]_{\mathrm{D}}{ }^{25} \cdot-7.4^{\circ}$ (c 0.3, DMF). ${ }^{1} \mathrm{H}\left(500 \mathrm{MHz}, \mathrm{D}_{2} \mathrm{O}\right): 3.74-3.82\left(6 \mathrm{H}, \mathrm{m},-\mathrm{CH}_{2}\right), 3.86-3.94\left(6 \mathrm{H}, \mathrm{m},-\mathrm{CH}_{2}\right), 4.38-4.41(2 \mathrm{H}, \mathrm{m},-\mathrm{CH}$ Ser). ${ }^{13} \mathrm{C}(125 \mathrm{MHz}) 42.3,42.5,55.9,60.2,171.7,171.8,172.3$. ESI-HRMS: $\mathrm{m} / z$ for $[\mathrm{M}+\mathrm{H}]^{+}$ Calculated $\left(\mathrm{C}_{14} \mathrm{H}_{23} \mathrm{~N}_{6} \mathrm{O}_{8}\right)$ 403.1577, found 403.1577; for $[\mathrm{M}+\mathrm{Na}]^{+}$Calculated $\left(\mathrm{C}_{14} \mathrm{H}_{22} \mathrm{~N}_{6} \mathrm{O}_{8} \mathrm{Na}\right)$ 425.1397 found 425.1396.

Boc-L-(O-propargyl)-Ser-OH (8). ${ }^{21 \mathrm{c}}$ Boc-L-Serine $(5 \mathrm{~g}, 24.36 \mathrm{mmol})$ was dissolved in dry DMF $(80 \mathrm{~mL})$ under nitrogen atmosphere. The solution was cooled to $0^{\circ} \mathrm{C}$ by using ice bath. Sodium hydride $(2.34 \mathrm{~g}, 60 \%$ in paraffin oil, $97.1 \mathrm{mmol})$ was then added and the mixture was stirred for about an hour until hydrogen gas evolution was finished. Propargyl bromide $(3.27 \mathrm{~mL}$, $80 \%$ in toluene, $36.48 \mathrm{mmol}$ ) was then added slowly at $0^{\circ} \mathrm{C}$ and the reaction mixture was further stirred for additional $3 \mathrm{~h}$. Water was added to quench the reaction, solvent was evaporated. The residue was dissolved in water $(30 \mathrm{~mL})$, solution was made acidic $(\mathrm{pH} 2-3)$ by adding aqueous citric acid solution. Compound was then extracted with ethyl acetate. The crude compound was purified through a silica gel column chromatography by using DCM/MeOH (95:5) solvent system to give pure compound as colorless oil. Yield $4.3 \mathrm{~g}(72 \%) . \mathrm{R}_{\mathrm{f}} 0.4(10 \% \mathrm{MeOH} / \mathrm{DCM}) .{ }^{1} \mathrm{H}$ NMR (500 MHz, $\mathrm{CDCl}_{3}, \mathrm{TMS}, \delta$ (ppm): $1.42\left(9 \mathrm{H}, \mathrm{s},-\mathrm{CH}_{3} \mathrm{Boc}\right), 2.42-2.43(1 \mathrm{H}, \mathrm{t}, J 2.3 \mathrm{~Hz}$, $\mathrm{C} \equiv \mathrm{H}$ propargyl), 3.77-3.80 (1H, dd, J 3.15 Hz, 9.15 Hz, $\left.-\mathrm{CH}_{2} \mathrm{Ser}\right), 3.95-3.97\left(1 \mathrm{H}, \mathrm{m},-\mathrm{CH}_{2} \mathrm{Ser}\right)$, 4.14-4.15 (2H, d, J 2.55 Hz, - $\mathrm{CH}_{2}$ propargyl), 4.43-4.45 (1H, m, -CH Ser), 5.39-5.41 (1H, d, $J$ $8.0 \mathrm{~Hz},-\mathrm{NH}$ amide). ${ }^{13} \mathrm{C}\left(125 \mathrm{MHz} ; \mathrm{CDCl}_{3}\right.$, TMS) $\delta$ (ppm): 28.4, 53.8, 58.7, 69.7, 75.2, 78.9, 80.2, 155.8, 173.7. ESI-HRMS: $m / z$ for $[\mathrm{M}+\mathrm{H}]^{+}$Calculated $\left(\mathrm{C}_{11} \mathrm{H}_{18} \mathrm{NO}_{5}\right)$ 244.1185, found 244.1184. for $[\mathrm{M}+\mathrm{Na}]^{+}$Calculated $\left(\mathrm{C}_{11} \mathrm{H}_{17} \mathrm{NO}_{5} \mathrm{Na}\right) 266.1004$, found 266.0964.

Boc-L-(O-propargyl)-Ser-Gly-OMe (9). 8 (4 g, 16.44 mmol) and 1-hydroxybenzotriazole (2.67 $\mathrm{g}, 17.5 \mathrm{mmol})$ were dissolved in dry DMF $(15 \mathrm{~mL})$ and DCM $(40 \mathrm{~mL})$, and reaction mixture was cooled to $0^{\circ} \mathrm{C}$ under nitrogen atmosphere. Solution of DCC (3.6 g, $\left.17.44 \mathrm{mmol}\right)$ in DCM (15 mL) was added into the reaction mixture at $0^{\circ} \mathrm{C}$ under nitrogen atmosphere. The reaction mixture was stirred at $0{ }^{\circ} \mathrm{C}$ for half an hour. Hydrochloride salt of glycine methylester (2.06 g, $16.44 \mathrm{mmol}$ ) was then added into the reaction mixture followed by the addition of triethylamine $(4.6 \mathrm{~mL}, 32.8$ $\mathrm{mmol}$ ) and stirring was continued for $15 \mathrm{~h}$ at room temperature. Next, the reaction mixture was filtered to remove $N, N^{\prime}$-dicyclohexylurea and filtrate was concentrated in reduced pressure. The residue was dissolved in ethylacetate and organic layer was washed with aqueous $10 \%$ aqueous citric acid solution and $10 \%$ aqueous $\mathrm{NaHCO}_{3}$ solution. The organic layer was then dried over anhydrous sodium sulphate and concentrated under reduced pressure. The crude compound was purified through a silica gel column chromatography by using pet ether/ethylacetate (4:2) solvent 
system to give pure compound as colourless oil. Yield $3.98 \mathrm{~g}$, (78\%). $\mathrm{R}_{\mathrm{f}}$ : 0.5 (50\% ethyl acetate/pet ether). $[\alpha]_{\mathrm{D}}{ }^{25}+4.95^{\circ}\left(c 0.34, \mathrm{CH}_{3} \mathrm{OH}\right) .{ }^{1} \mathrm{H}$ NMR $\left(500 \mathrm{MHz}, \mathrm{CDCl}_{3}, \mathrm{TMS}, \delta(\mathrm{ppm})\right.$ : $1.48\left(9 \mathrm{H}, \mathrm{s},-\mathrm{CH}_{3}\right.$ Boc), 2-44-2.45 (1H, t, J $2.6 \mathrm{~Hz},-\mathrm{C} \equiv \mathrm{H}$ propargyl), 3.65-3.68 (1H, dd, J 5.75 $\left.\mathrm{Hz}, 9.15 \mathrm{~Hz},-\mathrm{CH}_{2} \mathrm{Ser}\right), 3.73\left(3 \mathrm{H}, \mathrm{s},-\mathrm{OCH}_{3}\right), 3.92-3.94\left(1 \mathrm{H}, \mathrm{dd}, J 3.7 \mathrm{~Hz}, 9.15 \mathrm{~Hz},-\mathrm{CH}_{2} \mathrm{Ser}\right)$, $4.05\left(2 \mathrm{H}, \mathrm{s},-\mathrm{CH}_{2}\right.$ propargyl), 4.12-4.16 (1H, dd, J 2.3Hz, 15.75Hz, $\left.-\mathrm{CH}_{2} \mathrm{Gly}\right), 4.18-4.22$ (1H, dd, $J$ 2.6Hz, 15.75Hz, - $\mathrm{CH}_{2}$ Gly), $4.33(1 \mathrm{H}, \mathrm{s}, \mathrm{brd},-\mathrm{CH}$ Ser $), 5.40(1 \mathrm{H}, \mathrm{s},-\mathrm{NH}$ amide Boc $), 6.93(1 \mathrm{H}$, $\mathrm{s}$, -NH amide). ${ }^{13} \mathrm{C}\left(125 \mathrm{MHz} ; \mathrm{CDCl}_{3}\right.$, TMS) $\delta(\mathrm{ppm}): 28.4,41.4,52.5,53.9,58.7,69.4,75.4$, 79.0, 80.6, 155.6, 170.1, 170.4. ESI-HRMS: $m / z$ for $[\mathrm{M}+\mathrm{H}]^{+}$Calculated $\left(\mathrm{C}_{14} \mathrm{H}_{23} \mathrm{~N}_{2} \mathrm{O}_{6}\right) 315.1556$, found 315.1551; for $[\mathrm{M}+\mathrm{Na}]^{+}$calculated $\left(\mathrm{C}_{14} \mathrm{H}_{22} \mathrm{~N}_{2} \mathrm{O}_{6} \mathrm{Na}\right) 337.1376$, found 337.1327.

Boc-Gly-L-(O-propargyl)-Ser-Gly-OMe (10). 9 (3.8 g, 12.08 mmol) was dissolved in dissolved in $10 \mathrm{~mL}$ DCM. $10 \mathrm{~mL}$ of TFA was then added at room temperature and the reaction mixture was stirred for $2 \mathrm{~h}$ under nitrogen atmosphere. The solvent was evaporated under reduced pressure and the gummy residue obtained was triturated with diethyl ether and evaporated to yield solid compound. Yield $3.66 \mathrm{~g}(92 \%)$. $\mathrm{R}_{\mathrm{f}} \cdot 0.3$ (10\% methanol in dichloromethane).

Boc-Glycine (1.95 g, $11.14 \mathrm{mmol})$ and 1-hydroxybenzotriazole (1.87 g, $12.2 \mathrm{mmol})$ were dissolved in dry DMF $(15 \mathrm{~mL})$ and dichloromethane $(20 \mathrm{~mL})$, and reaction mixture was cooled to $0{ }^{\circ} \mathrm{C}$ under nitrogen atmosphere. Solution of DCC $(2.51 \mathrm{~g}, 12.18 \mathrm{mmol})$ in DCM $(15 \mathrm{~mL})$ was added into the reaction mixture at $0^{\circ} \mathrm{C}$ under nitrogen atmosphere. The reaction mixture was stirred at $0^{\circ} \mathrm{C}$ for half an hour. TFA salt of (O-propargyl)-Ser-Gly-methyl ester (3.66 g, 11.14 $\mathrm{mmol}$ ) was then added into the reaction mixture followed by the addition of triethylamine (2.96 $\mathrm{mL}, 21.1 \mathrm{mmol}$ ) and stirring was continued for $15 \mathrm{~h}$ at room temperature. Next, the reaction mixture was filtered to remove $N, N^{\prime}$-dicyclohexylurea and filtrate was concentrated in reduced pressure. The residue was dissolved in ethyl acetate and organic layer was washed with aqueous $10 \%$ aqueous citric acid solution and $10 \%$ aqueous $\mathrm{NaHCO}_{3}$ solution. The organic layer was then dried over anhydrous sodium sulphate and concentrated under reduced pressure. The crude compound was purified through a silica gel column chromatography by using DCM/MeOH (97:3) solvent system to give pure compound as colorless oil. Yield $3.38 \mathrm{~g}(82 \%)$. $\mathrm{R}_{\mathrm{f}}: 0.6(10 \%$ $\mathrm{MeOH} / \mathrm{DCM}) .[\alpha]_{\mathrm{D}}{ }^{25}-3.04^{\circ}\left(c 0.39, \mathrm{CH}_{3} \mathrm{OH}\right) .{ }^{1} \mathrm{H}$ NMR $\left(500 \mathrm{MHz}, \mathrm{CDCl}_{3}, \mathrm{TMS}, \delta(\mathrm{ppm}): 1.46\right.$ (9H, s, $-\mathrm{CH}_{3}$ Boc), 2-45-2.46 (1H, t, J $2.3 \mathrm{~Hz},-\mathrm{C} \equiv \mathrm{H}$ propargyl), 3.66-3.69 (1H, dd, J $5.7 \mathrm{~Hz}$, $\left.9.45 \mathrm{~Hz},-\mathrm{CH}_{2}\right), 3.72\left(3 \mathrm{H}, \mathrm{s},-\mathrm{OCH}_{3}\right), 3.81-3.82\left(2 \mathrm{H}, \mathrm{d}, J 5.85 \mathrm{~Hz},-\mathrm{CH}_{2} \mathrm{Gly}\right), 3.94-3.99(2 \mathrm{H}, \mathrm{d}$, $J 3.4 \mathrm{~Hz},-\mathrm{CH}_{2}$ propargyl), 4.03-4.08 $\left(1 \mathrm{H}, \mathrm{dd}, J 5.4 \mathrm{~Hz}, 18 \mathrm{~Hz},-\mathrm{CH}_{2}\right), 4.13-4.16(1 \mathrm{H}, \mathrm{dd}, J 2.3$ $\left.\mathrm{Hz}, 16.05 \mathrm{~Hz},-\mathrm{CH}_{2}\right), 4.19-4.22\left(1 \mathrm{H}, \mathrm{dd}, J 5.3 \mathrm{~Hz}, 16.0 \mathrm{~Hz},-\mathrm{CH}_{2}\right), 4.64-4.68(1 \mathrm{H}, \mathrm{m},-\mathrm{CH} \mathrm{Ser})$, $5.34(1 \mathrm{H}, \mathrm{s},-\mathrm{NH}$ amide Boc), 7.02-7.03 $(1 \mathrm{H}, \mathrm{d}, J 7.45 \mathrm{~Hz},-\mathrm{NH}$ amide), $7.25(1 \mathrm{H}, \mathrm{s}, \mathrm{brd},-\mathrm{NH}$ amide). ${ }^{13} \mathrm{C}$ (125 MHz; $\mathrm{CDCl}_{3}$, TMS) $\delta$ (ppm): 28.4, 41.4, 44.5, 52.5, 52.6, 58.8, 69.0, 75.5, 79.0, 80.6, 156.5, 170.0, 170.1. ESI-HRMS: $m / z$ for $[\mathrm{M}+\mathrm{H}]^{+}$Calculated $\left(\mathrm{C}_{16} \mathrm{H}_{26} \mathrm{~N}_{3} \mathrm{O}_{7}\right) 3721771$, found 372.1772. for $[\mathrm{M}+\mathrm{Na}]^{+}$Calculated $\left(\mathrm{C}_{16} \mathrm{H}_{25} \mathrm{~N}_{3} \mathrm{O}_{7} \mathrm{Na}\right) 394.1590$, found 394.1523.

Boc-Gly-L-( $\boldsymbol{O}$-propargyl)-Ser-Gly-OH (11). 10 (1 g, $2.68 \mathrm{mmol})$ was dissolved in $10 \mathrm{~mL}$ of methanol. $\mathrm{NaOH}$ (122 mg, $3.05 \mathrm{mmol})$ as its aqueous solution was added and stirred for 3 hours at room temperature. Reaction mixture was then passed through strong cation exchange resin. Solvent was then evaporated to get the product as white solid. Yield $874 \mathrm{mg}(90 \%) . \mathrm{R}_{\mathrm{f}}: 0.3$ (10\% 
$\mathrm{MeOH} / \mathrm{DCM}) \cdot[\alpha]_{\mathrm{D}}{ }^{25}+1.08^{\circ}\left(c 0.67, \mathrm{CH}_{3} \mathrm{OH}\right) .{ }^{1} \mathrm{H}$ NMR $\left(500 \mathrm{MHz}, \mathrm{CDCl}_{3}, \mathrm{TMS}, \delta(\mathrm{ppm}): 1.42\right.$ $\left(9 \mathrm{H}, \mathrm{s},-\mathrm{CH}_{3} \mathrm{Boc}\right), 2.51-2.52\left(1 \mathrm{H}, \mathrm{t}, J 2.3 \mathrm{~Hz},-\mathrm{C} \equiv \mathrm{H}\right.$ propargyl), 3.71-3.81 (2H, m, - $\left.\mathrm{CH}_{2}\right), 3.87-$ $3.94\left(2 \mathrm{H}, \mathrm{m},-\mathrm{CH}_{2}\right), 4.00-4.05\left(2 \mathrm{H}, \mathrm{m},-\mathrm{CH}_{2}\right), 4.14-4.15\left(2 \mathrm{H}, \mathrm{d}, J 3.75 \mathrm{~Hz},-\mathrm{CH}_{2}\right.$ propargyl), 4.72-4.75 (1H, m, -CH Ser), $5.82(1 \mathrm{H}, \mathrm{s}$, brd, -NH amide Boc), 7.50-7.52 (1H, d, J 7.45 Hz, -NH amide), 7.65-7.67 (2H, m, -NH amide, $-\mathrm{COOH}) .{ }^{13} \mathrm{C}\left(125 \mathrm{MHz} ; \mathrm{CDCl}_{3}, \mathrm{TMS}\right) \delta(\mathrm{ppm}): 28.4$, 41.5, 44.2, 50.1, 58.6, 69.0, 75.7, 79.0, 84.8, 156.7, 170.7, 171.7, 172.1. ESI-HRMS: $m / z$ for $[\mathrm{M}+\mathrm{H}]^{+}$Calculated $\left(\mathrm{C}_{15} \mathrm{H}_{24} \mathrm{~N}_{3} \mathrm{O}_{7}\right) 358.1614$, found 358.1620 .

Boc-Gly-( $\boldsymbol{O}$-propargyl)-Ser-Gly-OPNP (12). 11 (850 mg, $2.38 \mathrm{mmol})$, p-nitrophenol (330 mg, $2.38 \mathrm{mmol})$ was dissolved in dry DCM $(10 \mathrm{~mL})$, and cooled $0^{\circ} \mathrm{Cin}$ ice bath. A solution of DCC $(540 \mathrm{mg}, 2.60 \mathrm{mmol})$ in dichloromethane was added slowly and stirred for 1 hour at $0^{\circ} \mathrm{C}$ temperature and then $5 \mathrm{~h}$ at room temperature. $N, N$ '-Dicyclohexylurea was filtered off and organic layer was washed with $10 \%$ aqueous $\mathrm{NaHCO}_{3}$ solution and then with brine solution. The organic layer was then dried over anhydrous sodium sulphate and concentrated in reduced pressure. The product obtained was used in the subsequent step without further purification. Yield $975 \mathrm{mg}(85 \%) . \mathrm{R}_{\mathrm{f}}$ : $0.5(5 \% \mathrm{MeOH} / \mathrm{DCM}) .[\alpha]_{\mathrm{D}}{ }^{25}+1.47^{\circ}\left(c 0.41, \mathrm{CH}_{3} \mathrm{OH}\right) .{ }^{1} \mathrm{H}$ NMR $(500$ $\mathrm{MHz}, \mathrm{CDCl}_{3}, \mathrm{TMS}, \delta(\mathrm{ppm}): 1.42\left(9 \mathrm{H}, \mathrm{s},-\mathrm{CH}_{3} \mathrm{Boc}\right), 2.45-2.46(1 \mathrm{H}, \mathrm{t}, J 2 \mathrm{~Hz},-\mathrm{C} \equiv \mathrm{H}$ propargyl), 3.69-3.72 (1H, dd, J 5.15 Hz, 9.45 Hz, $\left.-\mathrm{CH}_{2}\right), 3.79-3.80\left(2 \mathrm{H}, \mathrm{d}, J 5.45 \mathrm{~Hz},-\mathrm{CH}_{2} \mathrm{Gly}\right), 4.03-4.23$ $\left(4 \mathrm{H}, \mathrm{m},-\mathrm{CH}_{2}\right), 4.28-4.32\left(1 \mathrm{H}, \mathrm{dd}, J 5.75 \mathrm{~Hz}, 17.75 \mathrm{~Hz},-\mathrm{CH}_{2}\right), 4.67-4.70(1 \mathrm{H}, \mathrm{m}, \mathrm{CH} \mathrm{Ser}), 5.40$ (1H, s, -NH amide Boc), 7.06-7.08 (1H, d, J 7.75 Hz, -NH amide), 7.30-7.31 (2H, d, J 9.15 Hz, aromatic - $\mathrm{CH} \mathrm{PNP}), 7.62(1 \mathrm{H}, \mathrm{s}$, brd, $-\mathrm{NH}$ amide), 8.23-8.25 (2H, d, J 9.15 Hz, aromatic $-\mathrm{CH}$ $\mathrm{PNP}){ }^{13} \mathrm{C}\left(125 \mathrm{MHz} ; \mathrm{CDCl}_{3}\right.$, TMS) $\delta$ (ppm): 28.4, 41.7, 44.8, 52.8, 58.8, 68.8, 75.6, 78.9, 81.0, 122.4, 125.4, 145.6, 155.1, 156.8, 167.4, 170.0, 170.5. ESI-HRMS: $m / z$ for $[\mathrm{M}+\mathrm{H}]^{+}$Calculated $\left(\mathrm{C}_{21} \mathrm{H}_{27} \mathrm{~N}_{4} \mathrm{O}_{9}\right) 479.1778$, found 479.1795.

Cyclo[Gly-L-( $\boldsymbol{O}$-propargyl)Ser-Gly] $]_{2}$ (13). $12(950 \mathrm{mg}, 1.98 \mathrm{mmol})$ was taken in a round bottom flask dissolved in $3 \mathrm{~mL}$ DCM and $3 \mathrm{~mL}$ of TFA was then added at room temperature. The reaction mixture was stirred for $2 \mathrm{~h}$ under nitrogen atmosphere. The solvent was evaporated under reduced pressure and the gummy residue obtained was triturated with diethyl ether to yield compound as off white solid. Yield $920 \mathrm{mg}(93 \%)$. $\mathrm{R}_{\mathrm{f}} .0 .2$ (10\% methanol in dichloromethane).

DMF $(90 \mathrm{~mL})$ and triethylamine $(830 \mu \mathrm{L})$ was taken in a two necked R.B flask. Compound (900 $\mathrm{mg}, 1.82 \mathrm{mmol}$ ) was dissolved in $20 \mathrm{~mL} \mathrm{DMF}$ and added drop wise to the solution of DMF and TEA over a period of $4 \mathrm{~h}$ at room temperature. Then the reaction mixture was stirred at room temperature for 12 hours. DMF was then evaporated under reduced pressure. The crude product obtained was washed with diethyl ether $(3 \times 20 \mathrm{~mL})$, dichloromethane $(3 \times 10 \mathrm{~mL})$ and finally with 1:1 methanol: dichloromethane $(3 \times 15 \mathrm{~mL})$. TLC was monitored to see complete removal of $\mathrm{p}$ nitrophenol and any other UV active spots. The final solid was then dried in vacuum. Yield 175 mg (40\%). $[\alpha]_{\mathrm{D}}{ }^{25}-1.97^{\circ}$ (c 0.25, DMSO). ${ }^{1} \mathrm{H}$ NMR (500 MHz, DMSO- $d_{6}$, TMS, $\delta$ (ppm): 2.45 $\left(2 \mathrm{H}\right.$, merged with DMSO, $-\mathrm{C} \equiv \mathrm{H}$ propargyl), 3.61-3.84 $\left(12 \mathrm{H}, \mathrm{m},-\mathrm{CH}_{2}\right), 4.11\left(4 \mathrm{H}, \mathrm{s},-\mathrm{CH}_{2}\right.$ propargyl), 4.16-4.18 (2H, t, $J 6.3 \mathrm{~Hz},-\mathrm{CH}$ Ser), $7.56(2 \mathrm{H}, \mathrm{s},-\mathrm{NH}$ amide), 8.44 (2H, s, -NH amide), 8.53-8.54 (2H, d, $J 5.4 \mathrm{~Hz},-\mathrm{NH}$ amide). ${ }^{13} \mathrm{C}$ (125 MHz; DMSO- $\left.d_{6}, \mathrm{TMS}\right) \delta(\mathrm{ppm}): 42.3$, $42.8,54.2,68.5,78.0,80.4,169.6,170.1,170.2$ ESI-HRMS: $\mathrm{m} / z$ for $[\mathrm{M}+\mathrm{H}]^{+}$Calculated 
$\left(\mathrm{C}_{20} \mathrm{H}_{27} \mathrm{~N}_{6} \mathrm{O}_{8}\right)$ 478.1890, found 470.1891; [M+Na] $]^{+}$Calculated $\left(\mathrm{C}_{20} \mathrm{H}_{26} \mathrm{~N}_{6} \mathrm{O}_{8} \mathrm{Na}\right)$ 501.1710, found 501.1720 .

Mannose functionalized cyclo[Gly-L-(O-propargyl)Ser-Gly $]_{2}$ (Protected) (14). 13 (150 mg, $0.31 \mathrm{mmol})$, tetraacetylmannose azide $(296 \mathrm{mg}, 0.77 \mathrm{mmol})$, was suspended in water $(4 \mathrm{~mL})$ and tert-butanol $(5 \mathrm{~mL})$. Ascorbic acid $(107 \mathrm{mg}, 0.62 \mathrm{mmol})$ dissolved in water $(0.5 \mathrm{~mL})$ was added and the mixture was stirred for $5 \mathrm{~min}$ at room temperature. $\mathrm{CuSO}_{4} .5 \mathrm{H}_{2} \mathrm{O}(15.6 \mathrm{mg}, 0.063 \mathrm{mmol})$ solution (in $0.5 \mathrm{~mL}$ water) was subsequently added. The reaction mixture was then stirred for 15 $\mathrm{h}$ at room temperature. Solvent was then evaporated, methanol was added and filtered. Filtrate was evaporated and the crude product was purified by silica gel column chromatography using $\mathrm{DCM} / \mathrm{MeOH}$ (7: 3) as solvent system as light brown solid. Yield $230 \mathrm{mg}(60 \%) . \mathrm{R}_{\mathrm{f}} \cdot 0.3(20 \%$ $\mathrm{MeOH} / \mathrm{DCM}) .{ }^{1} \mathrm{H}$ NMR (500 MHz, CD $3 \mathrm{OD}, \mathrm{TMS}, \delta(\mathrm{ppm}): 1.99\left(6 \mathrm{H}, \mathrm{s},-\mathrm{OCH}_{3}\right), 2.02(6 \mathrm{H}$, s, $\left.\mathrm{OCH}_{3}\right), 2.04\left(6 \mathrm{H}, \mathrm{s},-\mathrm{OCH}_{3}\right), 2.16\left(6 \mathrm{H}, \mathrm{s},-\mathrm{OCH}_{3}\right), 3.85-3.88(8 \mathrm{H}, \mathrm{m}), 3.94-4.07(6 \mathrm{H}, \mathrm{m}), 4.16-$ $4.19(2 \mathrm{H}, \mathrm{m}), 4.30-4.34(4 \mathrm{H}, \mathrm{m}), 4.66\left(4 \mathrm{H}, \mathrm{s},-\mathrm{CH}_{2}\right.$ propargyl), 5.35-5.37 (2H, t, J 9.45 Hz, $\mathrm{CH}$ mannose), 5.86-5.88 (2H, dd, J $4 \mathrm{~Hz}, 9.45 \mathrm{~Hz}, \mathrm{CH}$ mannose), 5.92 (2H, s, brd, CH mannose), $6.27\left(2 \mathrm{H}, \mathrm{d}, J 2.3 \mathrm{~Hz}\right.$, anomeric $\mathrm{CH}$ mannose), $8.16\left(2 \mathrm{H}, \mathrm{s},-\mathrm{CH}\right.$ triazole). ${ }^{13} \mathrm{C}(125 \mathrm{MHz}$; $\left.\mathrm{CD}_{3} \mathrm{OD}, \mathrm{TMS}\right) \delta(\mathrm{ppm}): 19.2,19.3,41.7,42.2,57.9,61.5,63.6,65.8,68.0,69.2,72.1,75.2,83.9$, 124.5, 145.0, 169.9, 170.0, 170.8, 171.0. ESI-HRMS: $\mathrm{m} / z$ for $[\mathrm{M}+\mathrm{H}]^{+}$Calculated $\left(\mathrm{C}_{48} \mathrm{H}_{65} \mathrm{~N}_{12} \mathrm{O}_{26}\right)$ 1225.4133, found 1225.4133; [M+Na] ${ }^{+}$Calculated $\left(\mathrm{C}_{48} \mathrm{H}_{64} \mathrm{~N}_{12} \mathrm{O}_{26} \mathrm{Na}\right)$ 1247.3952, found 1247.3954.

Mannose functionalized cyclo[Gly-L-( $\boldsymbol{O}$-propargyl)Ser-Gly $]_{\mathbf{2}}$ (15). 14 (180 mg, $\left.0.15 \mathrm{mmol}\right)$ was dissolved in methanol $(5 \mathrm{~mL})$; sodium methoxide $(72 \mathrm{mg}, 1.35 \mathrm{mmol})$ was added and the reaction was stirred for $3 \mathrm{~h}$. During the course of the reaction precipitate was formed. $3 \mathrm{~mL}$ of water was added to dissolve the precipitate. The resulting solution was then neutralized by passing through strong cation exchange resin. Solvent was evaporated, the solid product obtained was washed with diethyl ether $(3 \times 10 \mathrm{~mL})$, dichloromethane $(3 \times 10 \mathrm{~mL})$ and finally with $1: 1$ methanol: dichloromethane $(3 \times 5 \mathrm{~mL})$. The residue was dissolved in $1 \mathrm{~mL}$ water and $5 \mathrm{~mL}$ of acetone was added to precipitate the compound. The supernatant solvent was discarded and the process was repeated for 3 times. Finally the off white hygroscopic solid was dried in vacuum. Yield $95 \mathrm{mg}(73 \%)$. $[\alpha]_{\mathrm{D}}{ }^{25}+15.74^{\circ}\left(c 0.25, \mathrm{H}_{2} \mathrm{O}\right) .{ }^{1} \mathrm{H}$ NMR $\left(500 \mathrm{MHz}, \mathrm{D}_{2} \mathrm{O}, \mathrm{TMS}, \delta(\mathrm{ppm})\right.$ : 3.16-3.25 $(6 \mathrm{H}, \mathrm{m}), 3.68-4.47(20 \mathrm{H}, \mathrm{m}), 4.59\left(4 \mathrm{H}, \mathrm{s},-\mathrm{CH}_{2}\right.$ propargyl), $6.00(2 \mathrm{H}, \mathrm{s}$, anomeric $\mathrm{CH}$ mannose), 8.07 (2H, s, -CH triazole). ${ }^{13} \mathrm{C}\left(125 \mathrm{MHz} ; \mathrm{D}_{2} \mathrm{O}, \mathrm{TMS}\right) \delta$ (ppm): 42.3, 48.9, 54.5, 58.4, $60.5,63.3,66.5,68.3,70.5,76.2,86.6,124.8,144.0,171.7,171.9,172.1$. ESI-HRMS: $m / z$ for $[\mathrm{M}+\mathrm{H}]^{+}$Calculated $\left(\mathrm{C}_{32} \mathrm{H}_{49} \mathrm{~N}_{12} \mathrm{O}_{18}\right) \quad 889.3288$, found $=889.3217 ;$ for $[\mathrm{M}+\mathrm{Na}]^{+}$Calculated $\left(\mathrm{C}_{32} \mathrm{H}_{48} \mathrm{~N}_{12} \mathrm{O}_{18} \mathrm{Na}\right)$ 911.3107, found 911.3104. 


\section{Acknowledgements}

AKB thanks CSIR for a senior research fellowship and NG thanks IIT Kanpur for a pre-doctoral fellowship. This work is supported by Department of Science and Technology, India, (SV) and by DST Unit of Excellence on Soft Nanofabrication at IIT Kanpur.

\section{References}

1. White, C. J.; Yudin, A. K. Nat. Chem. 2011, 3, 509.

2. Davies, J. S. J. Pept. Sci. 2003, 9, 471.

3. Turner, R. A.; Oliver, A. G.; Scott Lokey, R. Org. Lett. 2007, 9, 5011.

4. $\quad$ Lambert, J. N.; Mitchell, J. P.; Roberts, K. D. J. Chem. Soc., Perkin Trans. 1 2001, 471.

5. (a) Ghadiri, M. R.; Granja, J. R.; Milligan, R. A.; McRee, D. E.; Khazanovich, N. Nature 1993, 324, 366. (b) Bong, D. T.; Clark, T. D.; Granja, J. R.; Ghadiri, M. R. Angew. Chem. Int. Ed. 2001, 40, 988.

6. (a) Qin, S-Y.; Xu, X-D.; Chen, C-S.; Chen, J-X.; Li, Z-Y.; Zhuo, R-X.; Zhang, X-Z. Macromol Rapid Commun. 2011, 32, 758. (b) Qin, S-Y.; Chu, Y-F.; Tao, L.; Xu, S-S.; Li, Z-Y.; Zhuo, R-X.; Zhang, X-Z. Soft Matter 2011,7, 8635.

7. Hourani, R.; Zhang, C.; van der Weegen, R.; Ruiz, L.; Li, C.; Keten, S.; Helms, B. A.; Xu, T. J. Am. Chem. Soc. 2011, 133, 15296.

8. Montero, A.; Gastaminza, P.; Law, M.; Cheng, G.; Chisari, F. V.; Ghadiri, M. R. Chem. Biol. 2011, $18,1453$.

9. Liu, H.; Chen, J.; Shen, Q.; Fu, W.; Wu, W. Mol. Pharmaceutics 2010, 7, 1985.

10. (a) Kwak, B.; Shin, K,; Seok, S.; Kim, D.; Ahmad, F.; Geckeler, K. E.; Seeck, O. H.; Seo, Y-S.; Satijag, S. K.; Kubik, S. Soft Matter 2010, 6, 4701. (b) Motiei, L.; Rahimipour, S.; Thayer, D. A.; Wong, C-H.; Ghadiri, M. R. Chem. Commun. 2009, 3693.

11. (a) Joshi, K. B.; Verma, S. Angew. Chem., Int. Ed. 2008, 47, 2860. (b) Ghosh, S.; Singh, S. K.; Verma, S. Chem. Commun. 2007, 2296. (c) Ghosh, S.; Verma, S. Chem. Eur. J. 2008, 14, 1415. (d) Mondal, S.; Ghosh, S.; Verma, S. Tetrahedron Lett. 2010, 51, 856. (e) Gour, N.; Verma, S. Soft Matter, 2009, 5, 1789. (f) Barman, A. K.; Verma, S. Chem. Commun. 2010, 2296. (g) Joshi, K.B.;Verma, S. Supramol. Chem. 2006, 18, 405. (f) Joshi, K. B.; Verma, S. Tetrahedron 2007, 63, 5602. (h) Gour, N.; Barman, A. K.; Verma, S. J. Pept. Sci. 2012, 18, 405. (i) Gour, N.; Mondal, S.; Verma, S. J. Pept. Sci. 2011; 17, 148. (j) Gour, N.; Purohit, C. S.; Verma, S.; Puri, R.; Ganesh, S. Biochem. Biophys. Res. Commun. 2009, 378, 503. (k) Gour, N.; Verma, S. Tetrahedron 2008, 64, 7331.

12. Rinat, R.; Adler-Abramovich, L.; Ajish Kumar, K. S.; Kuan, T-C.; Lin, C-C.; Gazit, E.; Brik, A. Org. Biomol. Chem. 2011, 9, 5755.

13. 13.(a) Tian, Z.; Wang, M.; Zhang, A-Y.; Feng, Z-G. Polymer 2008, 49, 446. (b) Huang, Z-H.; Shi, J.; Ma, J-W.; Sun, Z-Y.; Cai, H.; Chen, Y-X.; Zhao, Y-F.; Li, Y-M. J. Am. Chem. Soc. 2012, 134 
, J.; Lecommandoux, S.; Heise, A. J. Am. Chem.Soc. 2012,

134, 119.

14. Mayorov, A. V.; Cai, M.; Palmer, E. S.; Liu, Z.; Cain, J. P.; Vagner, J.; Trivedi, D.; Hruby, V. J. Peptides 2010, 31, 1894.

15. (a) Ruiz-Gayo, M.; Royo, M.; Fernandez, I.; Albericio, F.; Giralt, E.; Pons, M. J. Org. Chem. 1993, 58, 6319. (b) Tulla-Puche, J.; Bayo-Puxan, N.; Moreno, J. A.; Francesch, A. M.; Cuevas, C.; Alvarez, M.; Albericio, F. J. Am. Chem. Soc. 2007, 129, 5322.

16. Iliev, B.; Linden, A.; Kunz, R.; Heimgartner, H.; Tetrahedron 2006, 62, 1079.

17. (a) Jagasia, R.; Holub, J. M.; Bollinger, M.; Kirshenbaum, K.; Finn, M. G. J. Org. Chem. 2009, 74, 2964. (b) Punna, S.; Kuzelka, J.; Wang, Q.; Finn, M. G. Angew. Chem. Int. Ed. 2005, 44, 2215.

18. Chakraborty, T. K.; Roy, S.; Koley, D.; Dutta, S. K.; Kunwar, A. C. J. Org. Chem. 2006, 71, 6240.

19. Haas, K.; Ponikwar, W.; Noth, H.; Beck, W. Angew. Chem. Int. Ed. 1998, 37, 1086.

20. Sokolenko, N.; Abbenante, G.; Scanlon, M. J.; Jones, A.; Gahan, L. R.; Hanson, G. R.; Fairlie, D. P. J. Am. Chem. Soc. 1999, 121, 2603.

21. (a) Rajca, A.; Wiessler, A. Carbohydr. Res. 1995, 274, 123. (b) Jadhav, S. V.; Bandyopadhyay, A.; Benke, S. N.; Mali, S. M.; Gopi, H. N. Org. Biomol. Chem. 2011, 9, 4182. (c) ten Brink, H. T.; Rijkers, D. T. S.; Liskamp, R. M. J. J. Org. Chem. 2006, 71, 1817.

22. (a) Martin, A. L.; Li, B.; Gillies, E. R. J. Am. Chem. Soc. 2009, 131, 734. (b) Thomas, G. B.; Rader, L. H.; Park, J.; Abezgauz, L.; Danino, D.; DeShong, P.; English, D. S. J. Am. Chem. Soc. 2009, 131, 5471.

23. Chien, M-P.; Rush, A. M.; Thompson, M. P.; Gianneschi, N. C. Angew. Chem. Int. Ed. 2010, 49, 5076.

\section{Graphical Abstract}

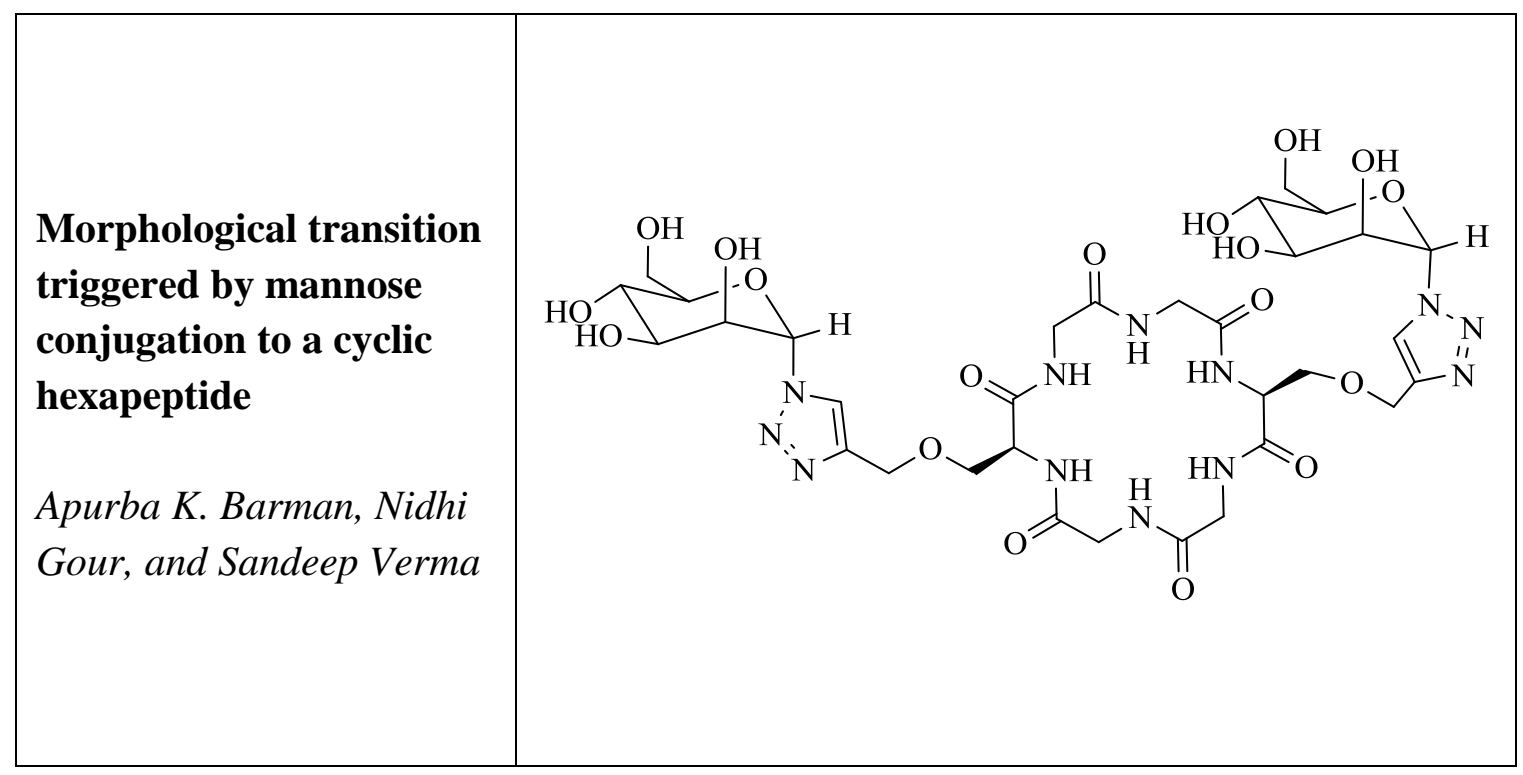

